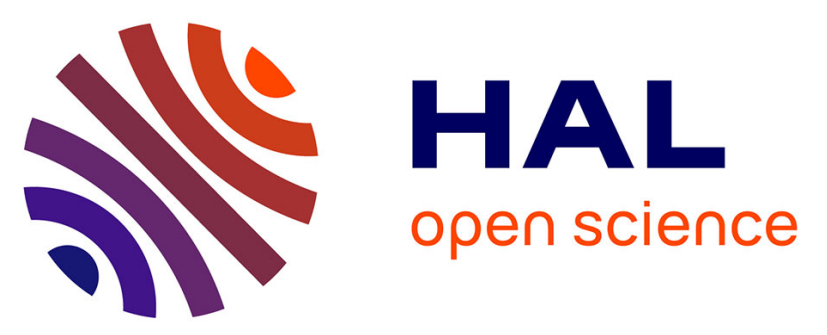

\title{
Influence of increasing convergence obliquity and shallow slab geometry onto tectonic deformation and seismogenic behavior along the Northern Lesser Antilles zone
}

Muriel Laurencin, D. Graindorge, F. Klingelhoefer, B. Marcaillou, M. Evain

\section{To cite this version:}

Muriel Laurencin, D. Graindorge, F. Klingelhoefer, B. Marcaillou, M. Evain. Influence of increasing convergence obliquity and shallow slab geometry onto tectonic deformation and seismogenic behavior along the Northern Lesser Antilles zone. Earth and Planetary Science Letters, 2018, 492, pp.59 - 72. 10.1016/j.epsl.2018.03.048. hal-01852728

\section{HAL Id: hal-01852728 \\ https://hal.science/hal-01852728}

Submitted on 28 Nov 2021

HAL is a multi-disciplinary open access archive for the deposit and dissemination of scientific research documents, whether they are published or not. The documents may come from teaching and research institutions in France or abroad, or from public or private research centers.
L'archive ouverte pluridisciplinaire HAL, est destinée au dépôt et à la diffusion de documents scientifiques de niveau recherche, publiés ou non, émanant des établissements d'enseignement et de recherche français ou étrangers, des laboratoires publics ou privés. 
1 Influence of increasing convergence obliquity and shallow slab

2 geometry onto tectonic deformation and seismogenic behavior 3 along the Northern Lesser Antilles zone

4 Laurencin M. ${ }^{1}$; Graindorge D. ${ }^{1}$, Klingelhoefer F. ${ }^{2}$, Marcaillou B. ${ }^{3}$, Evain M. ${ }^{2}$

${ }^{1}$ Geosciences Océan, UMR 6538, Université Bretagne Occidentale / Institut Universitaire Européen de la Mer, Place N. Copernic, 29280 Plouzané, France. ${ }^{2}$ Ifremer, Brest, France. ${ }^{3}$ Université Côte d'Azur, CNRS, Observatoire de la Côte d'Azur, IRD, Géoazur, 250 Rue Albert Einstein, 06560 Valbonne, France.

Corresponding author: Muriel Laurencin (muriel.laurencin@univ-brest.fr)

\section{Abstract}

In subduction zones, the 3D geometry of the plate interface is one of the key parameters that controls margin tectonic deformation, interplate coupling and seismogenic behavior. The North American plate subducts beneath the convex Northern Lesser Antilles margin. This convergent plate boundary, with a northward increasing convergence obliquity, turns into a sinistral strikeslip limit at the northwestern end of the system. This geodynamic context suggests a complex slab geometry, which has never been imaged before. Moreover, the seismic activity and particularly the number of events with thrust focal mechanism compatible with subduction earthquakes, increases northward from the Barbuda-Anguilla segment to the Anguilla-Virgin Islands segment. One of the major questions in this area is thus to analyze the influence of the increasing convergence obliquity and the slab geometry onto tectonic deformation and seismogenic behavior of the subduction zone. Based on wide-angle and multichannel reflection seismic data acquired during the Antithesis cruises (2013-2016), we decipher the deep structure of this subduction zone. Velocity models derived from wide-angle data acquired across the Anegada Passage are consistent with the presence of a crust of oceanic affinity thickened by hotspot magmatism and probably affected by the Upper Cretaceous-Eocene arc magmatism forming the 'Great Arc of the Caribbean'. The slab is shallower beneath the Anguilla-Virgin Islands margin segment than beneath the Anguilla-Barbuda segment which is likely to be directly related to the convex geometry of the upper plate. This shallower slab is located under the forearc where earthquakes and partitioning deformations increase locally. Thus, the shallowing slab might result in local greater interplate coupling and basal friction favoring seismic activity and tectonic partitioning beneath the Virgin Islands platform.

Keywords: Northern Lesser Antilles subduction; crust nature; interplate geometry; partitioning; interplate coupling; seismic data

\section{Introduction}

In subduction zones, the downgoing plate dynamics directly influence the upper plate deformation and geological processes such as uplift and subsidence within forearc and backarc, strain partitioning in oblique subduction (e.g. McCaffrey 1992), location of the volcanic arc (e.g. Syracuse and Abers 2006), and seismogenic potential (e.g. McCann et al. 1979). At shallow depths $(0-40-\mathrm{km})$, chemical reactions, fluid release within the subducting plate and upper plate nature can play a key role in behavior and geometry of the subduction interface (e.g. Barker et al. 2009 and references therin), such as in the Hikurangi interplate subduction (e.g. 
Barker et al. 2009). Many plates subduct under a curved margin (as Scotia, Marianas, Northern Chilean, Aleutian subductions ...). At large scale (0-600-km-depth), curved deformation front are often related with slab complex 3D geometry proposed by modeling (e.g. Schellart et al. 2007; Bonnardot et al. 2008) and observed in different real cases (e.g. Hayes et al. 2012). Subsequently, observed variations of nature and geometry of the subducting plate at shallower depths $(<40-\mathrm{km}$-depth) for curved margins can play a major role on subduction zone processes and upper plate deformation.

The northeast Caribbean margin is sharply curved with a NS-trending subduction line offshore of the Central Lesser Antilles progressively rotating northward to an E-W direction to the north of the Greater Antilles (Figures 1 and 2). On the one hand, the $\mathrm{N} 254^{\circ} \mathrm{E}$ convergence direction does not change along-strike resulting in an arcuate slab with a westward dip beneath the Central Lesser Antilles and a southward dip beneath Puerto Rico and Hispaniola islands. On the other hand, the Lesser Antilles margin presents heterogeneities in seismicity (McCann and Sykes 1984) and partitioning (Laurencin et al. 2017) locations. The Antithesis 1 (11/201301/2014) and Antithesis 3 (05/2016) cruises were aimed at studying the deep structure and the tectonic deformation of the poorly investigated Northern Lesser Antilles margin (BarbudaVirgin Islands). Subsequently, using combined wide-angle and deep multichannel seismic data, we investigated the geometry of the downgoing slab and the nature of the overriding crust in order to discuss its influence onto partitioning deformation and seismic coupling.

\section{Geodynamical setting}

\subsection{Nature and origin of the eastern Caribbean region}

The eastern Caribbean plate, bounded by convergent margin from the southeast of Cuba to the south of the Lesser Antilles, includes an active island arc (Lesser Antilles arc) and a remnant arc, named the 'Great Arc of the Caribbean' (currently the Greater Antilles and the Aves Ridge), setting up on the 'Caribbean Plateau' (Figures 1 and 2). Two competing models depict the 'Caribbean Plateau' formation. The 'Pacific' model proposes an initiation of the 'Caribbean Plateau' within the Pacific plate during Jurassic, thickened during the Cretaceous by magmatism above a mantle plume (Galapagos), (Figure 1-A-B), and later drifted to its present position between the two American plates (e.g. Pindell and Kennan 2009). On the contrary, the 'in situ' model suggests that the thickening by decompression melting during MidCretaceous of the 'Proto-Caribbean' oceanic crust, forms the 'Caribbean Plateau' (Meschede and Frisch 1998; James 2009), (Figure 1-A'-B').

The subduction of Atlantic lithosphere beneath the Caribbean plate since at least Cretaceous to Eocene times forms the 'Great Arc of the Caribbean'. Fragments of this volcanic arc can be found in the residual Greater Antilles islands for Aptian times and in Puerto Rico for midEocene times (Jolly et al. 2008; Boschman et al. 2014), (Figure 1-AB-A'B'-C).

During the Eocene (Figure 1-D), the arc volcanism likely migrated eastward from the Aves Ridge to the Lesser Antilles arc caused by the collision of the Bahamas on the northern Caribbean margin (Bouysse et al. 1985; Neill et al. 2011), (Figure 1-D). This Lesser Antilles arc was active from Eocene to Oligocene (Bouysse and Westercamp 1990). During the Oligocene (Figure 1-E), the Lesser Antilles arc moved westward to its current position possibly due to slab flattening or in response to the subduction of the Barracuda and Tiburon ridges in the Central Antilles (Bouysse and Westercamp 1990). 
Wide-angle seismic data acquired in the Central (Kopp et al. 2011) and Southern Lesser Antilles (Christeson et al. 2008) image a 25-km-thick crust which is interpreted as being of oceanic affinity thickened by magmatism, coincident with the first steps of both geodynamic models. Moreover, Christeson et al. (2008) conclude that the subduction magmatism forming the 'Great Arc of the Caribbean' and that of the Lesser Antilles are comparable and do not imply variations in crustal velocities. Finally, the volcanism forming the 'Great Arc of the Caribbean' and the Lesser Antilles arc has a very low production rate and a local magmatic extension (Christeson et al. 2008; Kopp et al. 2011).
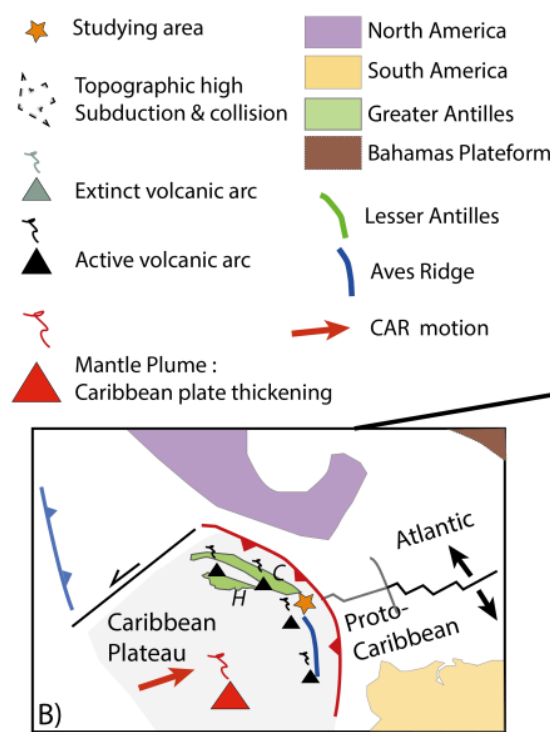

Late-Cretaceous

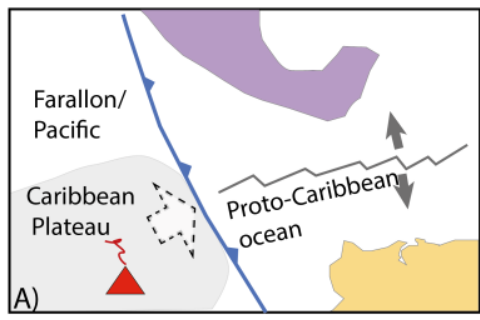

'Pacific model'

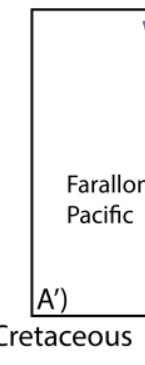

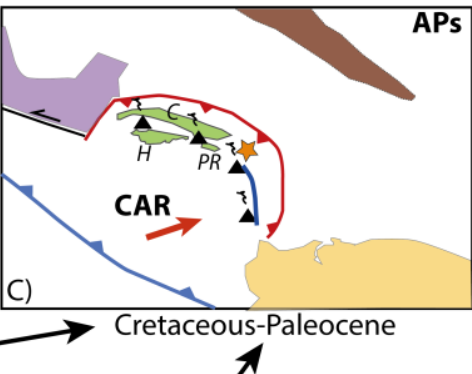

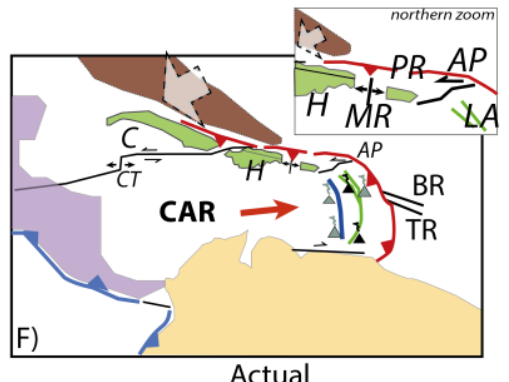

$\pi$
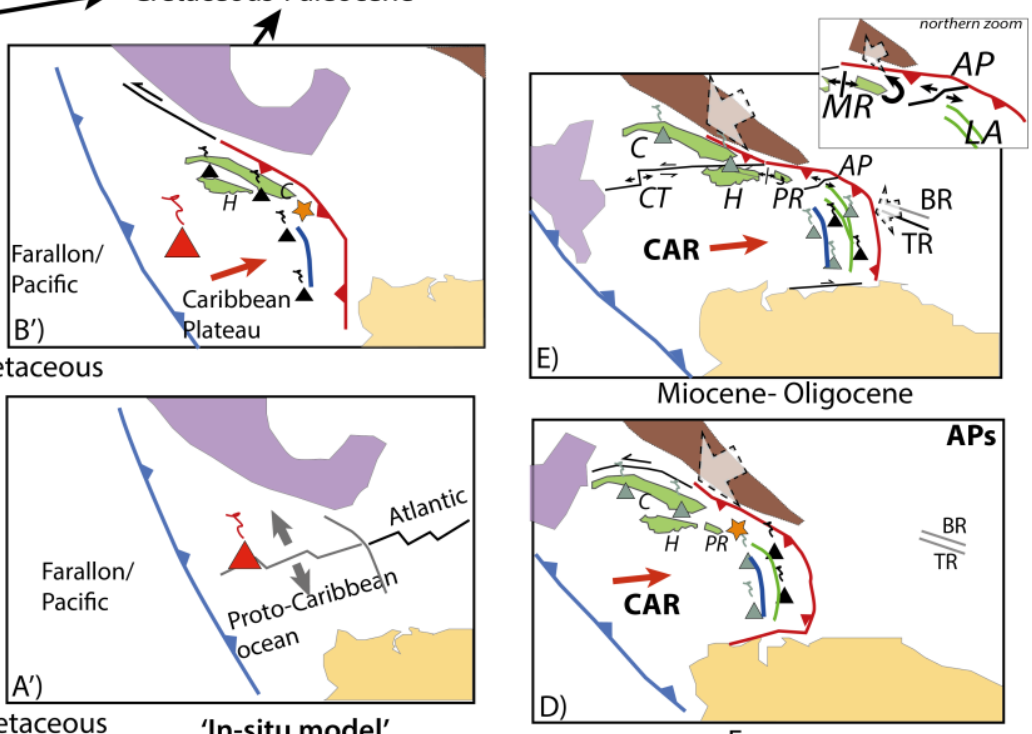

Eocene

Figure 1: Two alternate geodynamic reconstructions for the Caribbean Plate since Mid-Cretaceous: the 'Pacific model' (A-B) from Pindell and Kennan (2009) and Boschman et al. (2014), the 'in-situ' model (A'B') from Meschede and Frisch (1998) and James (2009). These reconstructions include (C$D)$ the collision of the Bahamas Bank, (E) the westward migration of the Lesser Antilles volcanic arc (Bouysse and Westercamp, 1990); the rotation of Puerto Rico-Virgin Islands bloc (Reid et al., 1991); the Mona rift and Anegada Passage opening (P. Mann et al. 2005; Laurencin et al. 2017) and (F) the current tectonic partitioning (Laurencin et al., 2017). AP: Anegada Passage; APs: American plates; BR: Barracuda Ridge; C: Cuba; CAR: Caribbean plate; CT: Cayman Trough; H: Hispaniola; MR: Mona rift; PR: Puerto Rico; TR: Tiburon Ridge

\subsection{The Northern Lesser Antilles regional setting}

The North American plate subducts below the Caribbean plate with a convergence rate of 20 $\mathrm{mm} / \mathrm{y}$ in a $\mathrm{N} 254^{\circ} \mathrm{E}$ direction (DeMets et al. 2000), (Figure 1-F). The convexity of the eastern part of the Caribbean plate implies a subduction obliquity less than $30^{\circ}$ to the south of Barbuda and increasing northward to $\sim 72^{\circ}$ to the north of Puerto Rico (Figure 2).

Partitioning of the tectonic deformation is frequent within margins that undergo oblique plate convergence (e.g. Fitch 1972). At the Northern Lesser Antilles subduction zone, the strain 
partitioning is possibly accommodated by 1) a $~ 600$ x $250 \mathrm{~km}$ northward migrating sliver 111 bounded by a major sinistral strike-slip system in the volcanic arc (López et al. 2006), or 2) arc112 perpendicular grabens bounded by ENE-WSW-trending normal faults (Feuillet et al. 2011). 113 Both interpretations suggest a total partitioning of the forearc. These models are still highly 114 debated. A recent interpretation of the first deep seismic data ever recorded in the Northern Lesser Antilles indicates that 1) the 850-km-long sinistral strike-slip Bunce fault (Ten Brink et al. 2004) located in the frontal part of the margin, extends as far south as offshore Barbuda island (Laurencin et al. 2017) and 2) the inherited 450-km-long left-lateral strike-slip system named Anegada Passage extends through the arc and the forearc from southeast of Puerto Rico to the Bunce fault (Laurencin et al. 2017), (Figure 2).

120 Hypocenter locations (McCann and Sykes 1984) and earthquake tomography (e.g. Van

121 Benthem et al. 2013) suggest a complex shape for this arcuate slab where it plunges toward the south, north of Hispaniola-Puerto Rico and toward the west at the Central Lesser Antilles. In the Northern Lesser Antilles, it possibly includes local dip angle variations accommodated by a tear fault near Puerto Rico (Ten Brink 2005; Meighan et al. 2013).

The recent seismicity is heterogeneous in the Lesser Antilles region. The number of shallow, 0-40-km-depth, earthquakes (PDE/NEIC catalog, $\mathrm{Mw}>5$, since 1900) and thrust focal mechanism earthquakes (CMT database: http://www.globalcmt.org, Mw > 3, since 1976) is low along the Barbuda-Anguilla segment. This seismicity increases south of Barbuda toward the Central Lesser Antilles and northward in the Anguilla-Virgin Islands segment (Figure 2). Three historical earthquakes were recorded in the Northern Lesser Antilles: 1690, 1843, 1867 (Bernard and Lambert 1988; Feuillet et al. 2011), (Figure 2). But, only one event, the 1843 earthquake $(\mathrm{M}>8.5)$ is possibly interpreted as a great subduction earthquake (Bernard and Lambert 1988; Feuillet et al. 2011). This heterogeneous distribution draws a seismic gap from Barbuda to Anguilla islands that previous studies already pointed out (e.g. Mccann and Sykes 1984). This gap is either temporal or related to long-term variations in interplate seismic coupling (e.g. Symithe et al. 2015).

137 Based on GPS data, Manaker et al. (2008) and Symithe et al. (2015) propose a very low coupling along the Lesser Antilles and Puerto Rico subduction interface resulting in an poorly coupled margin or in a 2000-years-long seismic cycle. 


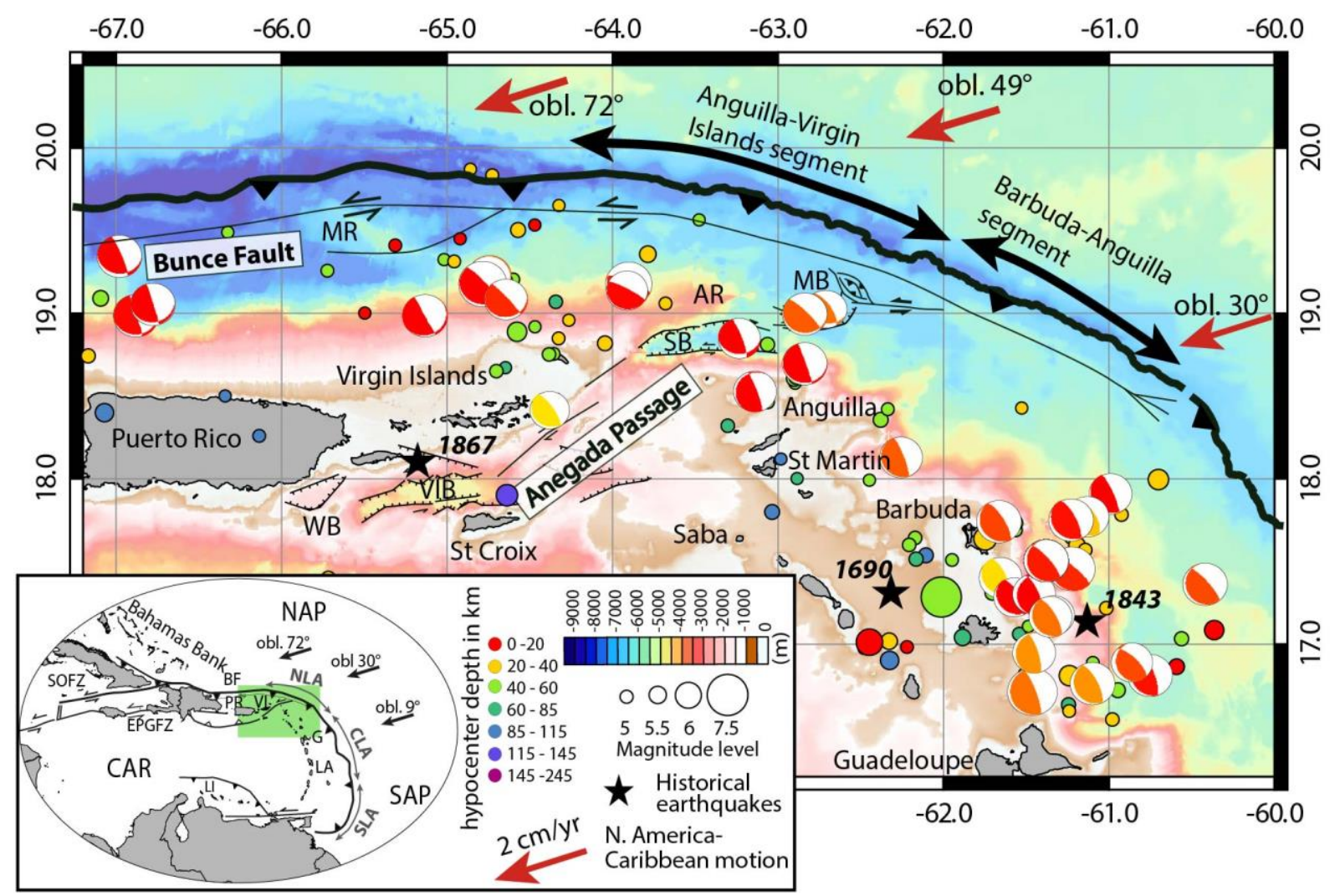

143 Figure 2: Seismicity along the Lesser Antilles margin. The colored circles are the epicenters and the

144 beach-balls represent the focal mechanism from PDE/NEIC catalog with size and color representing 145 magnitude and hypocentral depth. Subduction focal mechanisms from Global CMT Catalog and colors 146 represents the depth. Tectonic features are from Jany et al. (1990); ten Brink et al. (2004); Laurencin 147 et al. (2017). The black stars represent three historical earthquakes. The red arrows correspond to 148 convergence vector between North American and the Caribbean Plates (DeMets et al. 2000). AR: 149 Anegada Ridge; BF: Bunce Fault; MB: Malliwana Basin; MR: Main Ridge; SB: Sombrero Basin; VIB: 150 Virgin Islands Basin; WB: Whiting Basin. Bottom left inset displays larger tectonic setting with position 151 of Northern Lesser Antilles (NAP), Central Lesser Antilles (CLA) and Southern Lesser Antilles (SLA). 152 CAR: Caribbean Plate; EPGFZ: Enriquillo-Plantain Garden Fault Zone; G: Guadeloupe; LA: Lesser 153 Antilles; LI: Leeward Islands; NAP: North American Plate; PR: Puerto Rico; SAP: South American 154 Plate; SOFZ: Septentrional-Oriente Fault Zone; VI: Virgin Islands. 


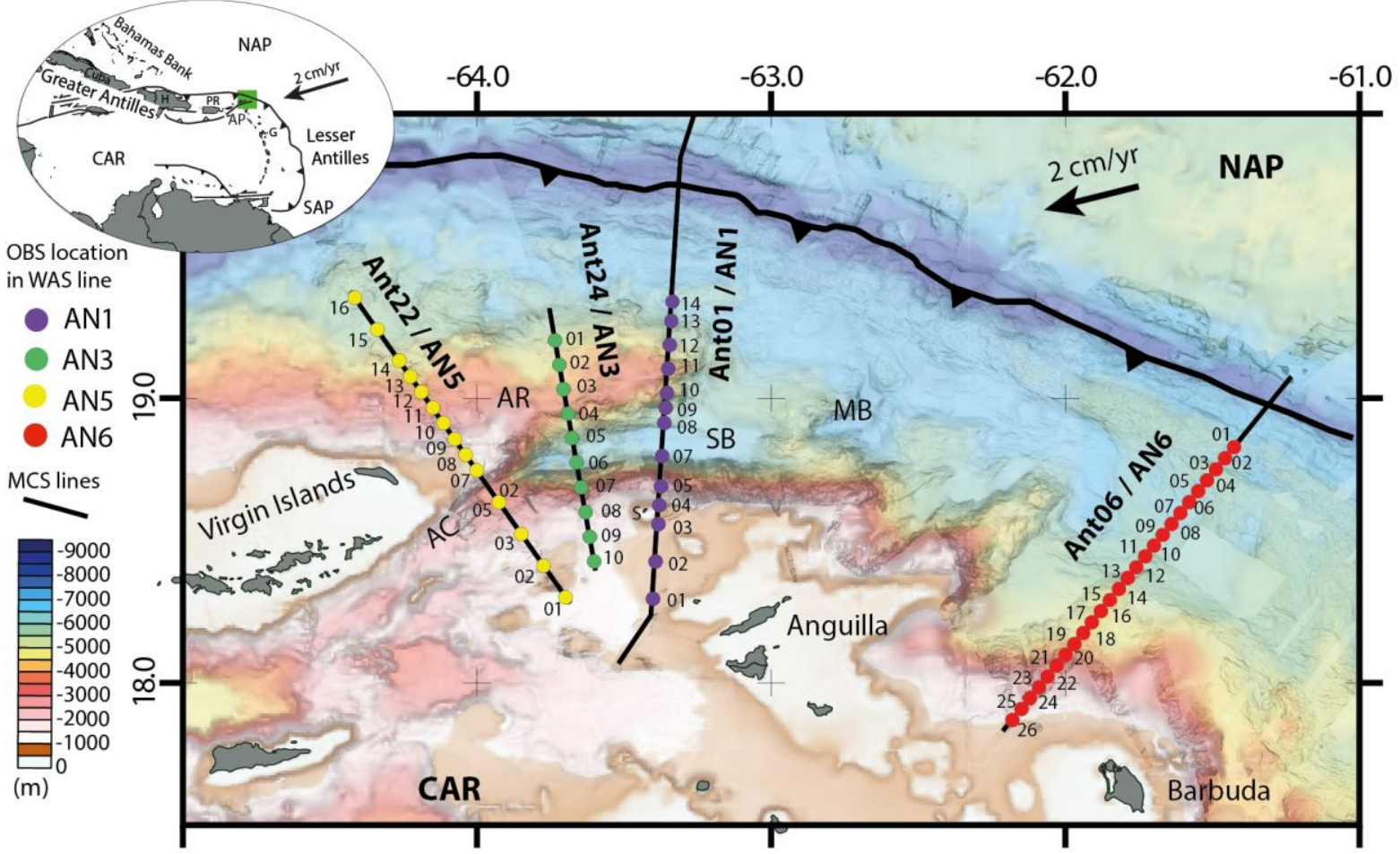

Figure 3: Location of Ocean Bottom Seismometers (colored circle), wide-angle and multichannel reflection seismic lines (solid line) recorded during the Antithesis cruise (Marcaillou and Klingelhoefer 2013). Top left inset displays larger tectonic setting. A: Anguilla, AC: Anegada Canyon, AR: Anegada Ridge; G: Guadeloupe, MB: Malliwana Basin, SB: Sombrero Basin, CAR: Caribbean Plate, NAP: North American Plate, SAP: South American Plate.

During the cruises Antithesis 1 and 3, four combined multichannel (MCS) and wide-angle seismic (WAS) lines were acquired along with multibeam bathymetric data (Figure 3). We recorded WAS data along lines AN1, AN3, AN5 and AN6, onboard R/V L'Atalante, with a 126 $\mathrm{L}\left(7699 \mathrm{in}^{3}\right)$ airgun array, and 40 ocean-bottom seismometers (OBS) from the Ifremer/UBO pool. The OBS include a three component $4.5 \mathrm{~Hz}$ geophone and one $3 \mathrm{~Hz}$ hydrophone (Auffret et al. 2004). We acquired MCS lines Ant01 and Ant06, which correspond to wide-angle lines AN1 and AN6, during cruise Antithesis 1 with a 3.75-km-long 300-channels streamer. We acquired MCS lines Ant22 and Ant24, which correspond to wide-angle lines AN3 and AN5, during cruise Antithesis 3 onboard R/V Pourquoi Pas?, using a $106 \mathrm{~L}$ (6500 in ${ }^{3}$ ) airgun array and a 4.5-km-long 720-channels streamer. The combined WAS and MCS lines AN1/Ant01, AN3/Ant24 and AN5/Ant22 image the structure of the Anguilla-Virgin Islands segment and line AN6/Ant06 visualizes the depth structure between Barbuda and Anguilla.

\subsection{Pre-processing of wide-angle seismic data}

The OBS data pre-processing includes the correction for clock drifts and the instrument relocation for spatial drift using the water wave arrival and shot geometry. The mean horizontal drift compared to the deployment position during the diving period is $185 \mathrm{~m}$ and up-to $\sim 600 \mathrm{~m}$. In order to increase signal-to-noise ratio and facilitate the identification of far offset arrivals, 
several processing steps were applied on the OBS data including: band-pass filtering, deconvolution and automatic gain control (Figure 4).

\subsection{Velocity modelling profiles}

\subsubsection{Method and WAG modeling}

The forward modelling consists of 2D ray tracing within a determined velocity-depth model to reduce the misfit between observed and calculated travel-times of both refracted and reflected arrivals (Zelt and Smith 1992). Models are built from top to bottom following a layer-stripping approach with interfaces defined by velocity and depth nodes. Refracted and reflected arrivals picking was done using the different unfiltered and filtered record sections on both hydrophone and geophones components.

The Figure 4 displays 6 interpreted OBS sections ( 2 per wide-angle lines), additional OBS sections with and without interpretation are shown in the supplementary data. Models include two to four sedimentary layers determined using reflected (Ps1 to Ps4) and refracted (Ps1P to Ps4P) phases (Figure 4). Picking the sedimentary interfaces along the coincident MCS lines helps to constrain geometries of the sedimentary layers for the wide-angle models (seismic preprocessing and processing in Laurencin et al. (2017) and in supplementary material). The Pwave velocity derived from OBS data allows the depth conversion of the picked interfaces. We used refracted $(\mathrm{Pc} 1, \mathrm{Pc} 2, \mathrm{Pc} 3, \mathrm{Pc} 4)$ and reflected $(\mathrm{Pc} 1 \mathrm{P}, \mathrm{Pc} 2 \mathrm{P}, \mathrm{Pc} 3 \mathrm{P}, \mathrm{Pc} 4 \mathrm{P})$ phases of wideangle data to define the three or four crustal layers (Figure 4). The reflected arrivals on the upper mantle of the upper plate $(\mathrm{Pc} 4 \mathrm{P})$ are clear, but the velocities at depth are poorly constrained because of the scarcity of refracted arrivals in the mantle wedge (Pn) (Figure 4). The top of the oceanic plate is generally better constrained by wide angle reflected arrivals (Pc4P) (Figure 4) and by interpretation of coincident MCS lines. No clear turning ray arrivals from the subducting oceanic plate were identified, and only few reflected phases from its base could be picked (PmP) (Figure 4). Thus, the velocity and the thickness of the oceanic plate are relatively poorly constrained by the velocity modeling only. Beneath the Sombrero Basin along the lines AN1 and AN3 (Figure 5-A), despite the fact that some arrivals are identifiable, it was impossible to adjust a definitive model (numerical instability of the code when calculating ray paths in complex structures) because of a high lateral variability of the structure within the Anegada Passage. 


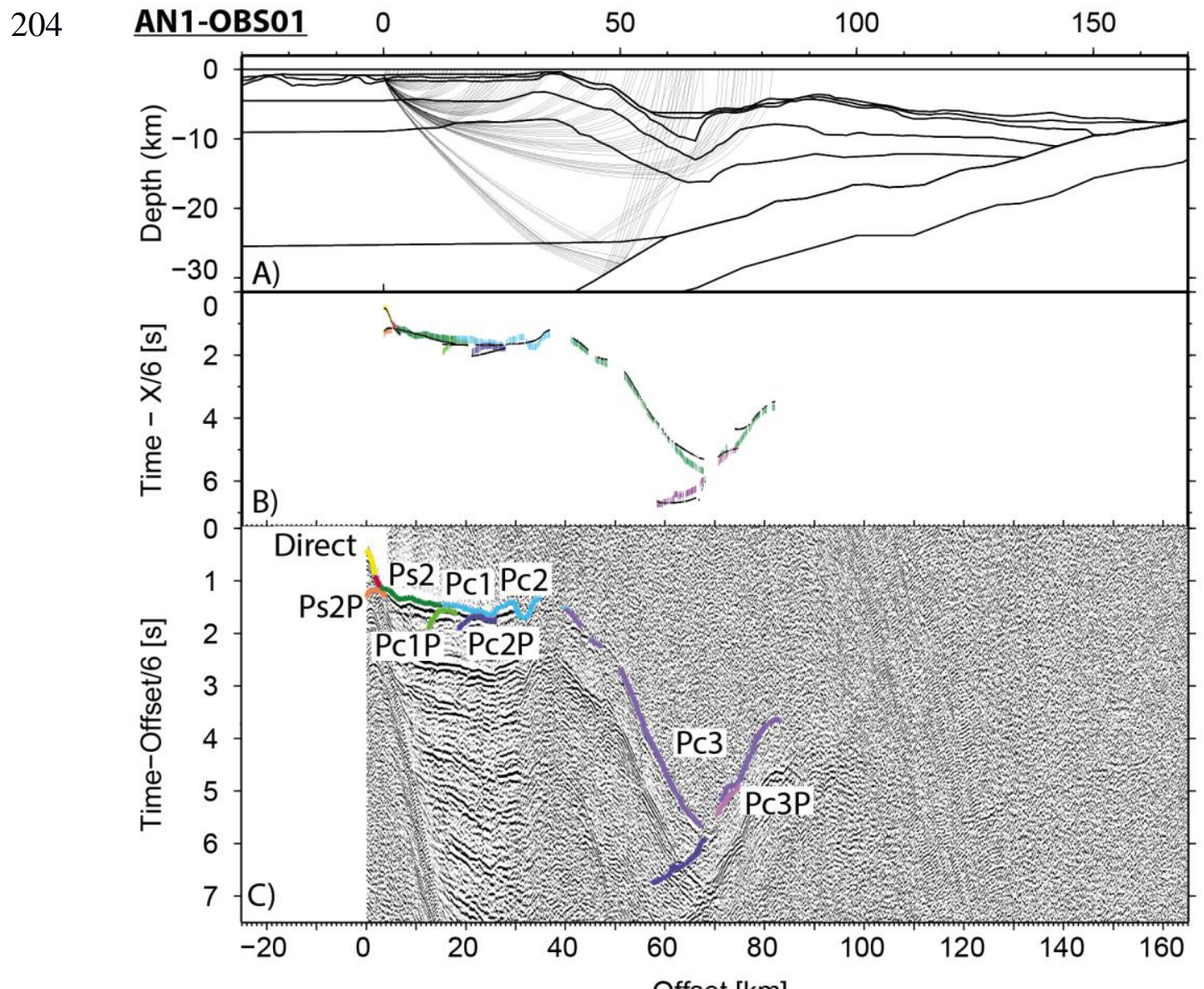
AN1-OBS13 0
50
100
150

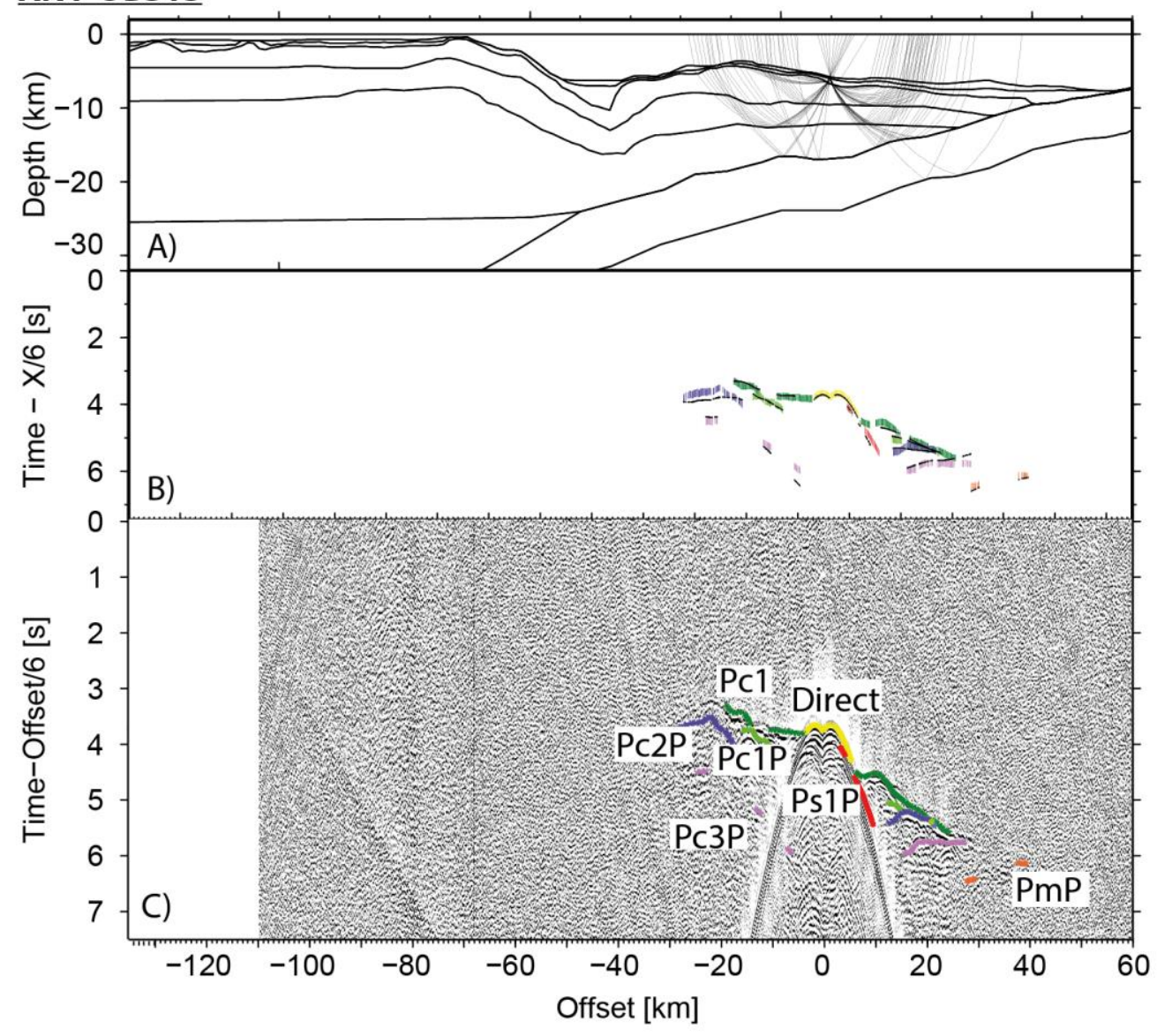



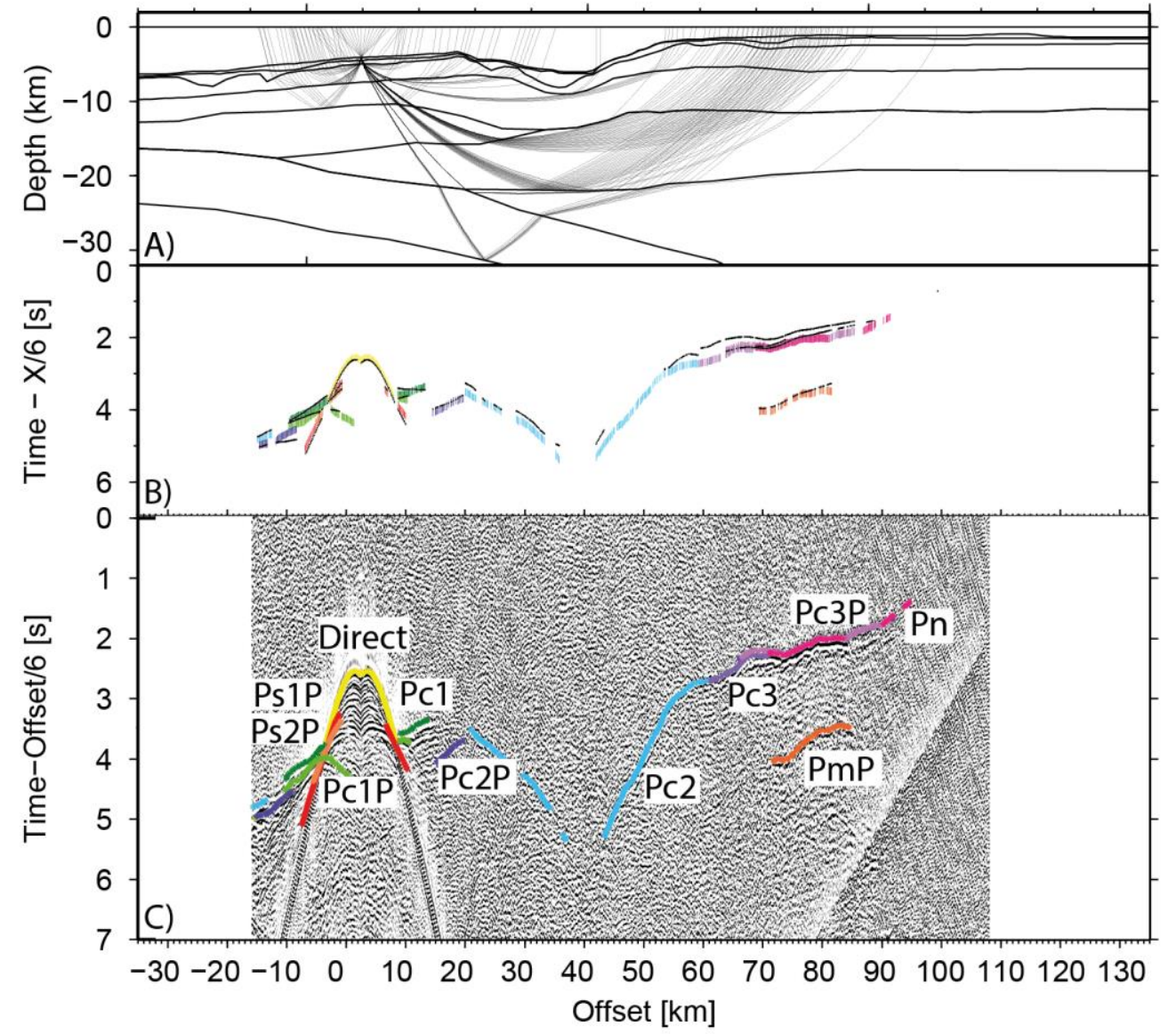

$\begin{array}{lllll}\text { AN3-OBS09 } & 0 & 50 & 100 & 150\end{array}$

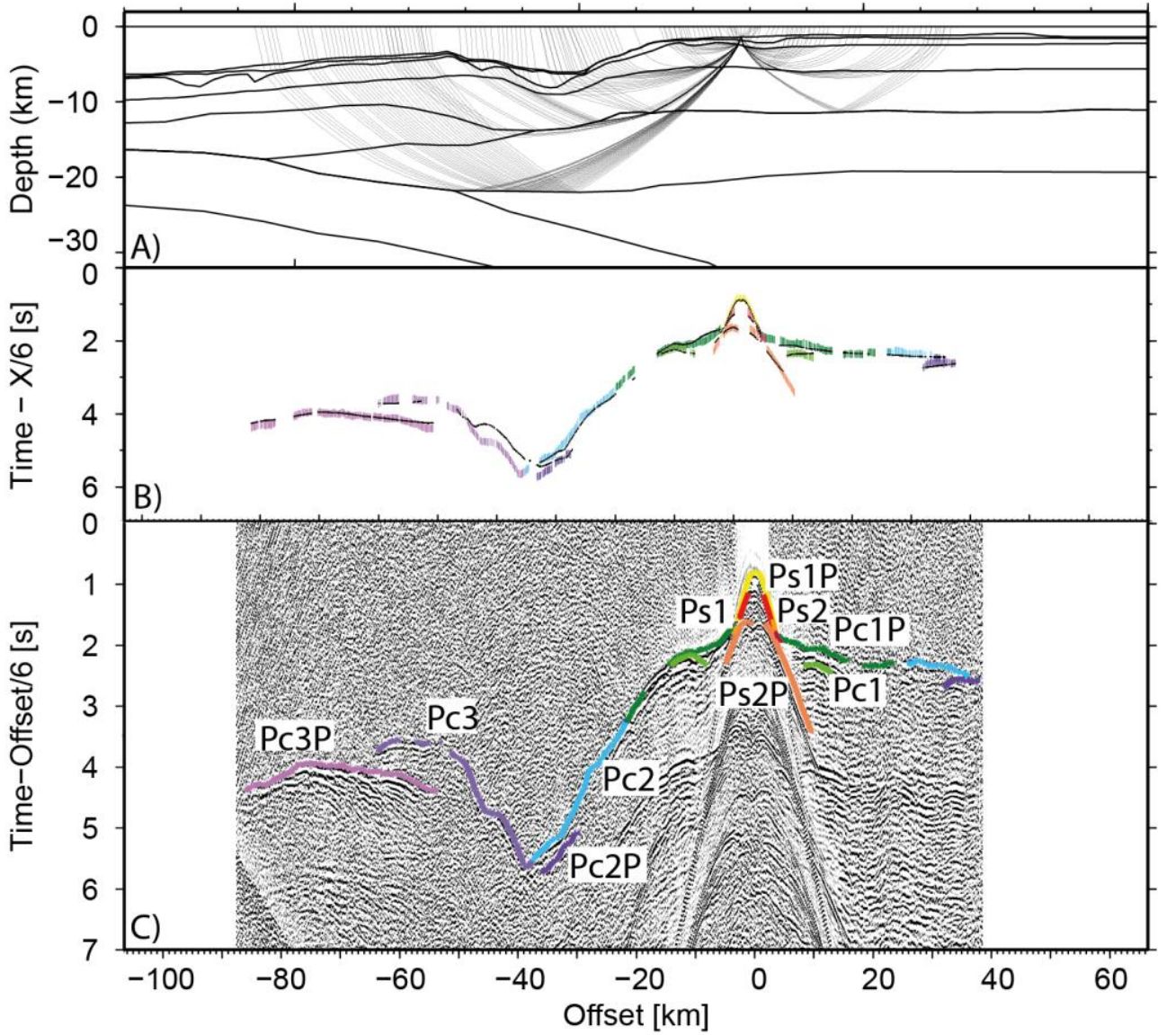



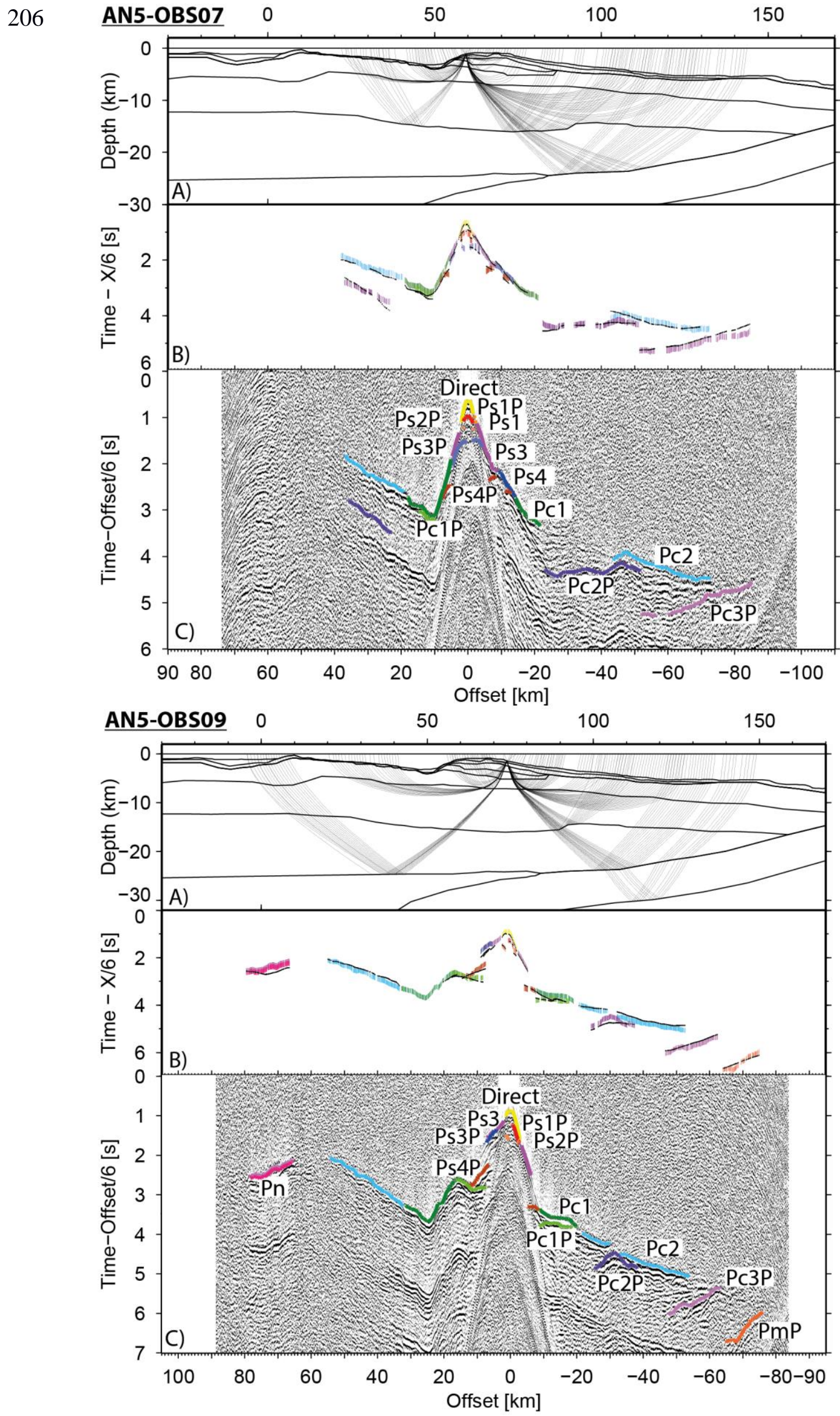
Figure 4: Modeled ray paths and wide-angle seismic sections for six different OBSs (see Figure 3 for instruments location). For each panel, (A) Ray coverage every fifth ray plotted. (B) Observed travel times (colored bars) according to phases picks and calculated travel time (solid lines). (C) OBS seismic section with picked phases. P-wave refracted phase through the nth sedimentary layer (PSn), the nth crust layer $(P c n)$, the Moho mantle for the upper plate (Pn). P-wave reflected phase on the bottom of the nth sedimentary layer $(P s n P)$, the nth crust layer $(P c n P)$, on the Moho interface of the subducting plate $(P m P)$. P-wave reflected phase on top of the subducting plate under the mantle phase of upper plate (PcoP).

\subsubsection{Error analysis}

Uncertainty and quality of the velocity models can be evaluated according to several parameters described in the following paragraphs.

The root mean square (RMS) error evaluates the misfit between calculated and observed travel times. The global RMS errors are respectively $0.150 \mathrm{~ms}$ for model AN5, $0.158 \mathrm{~ms}$ for model AN1, and $0.167 \mathrm{~ms}$ for model AN3. RMS errors range from $0.060 \mathrm{~ms}$ for direct wave to 0.291 ms for far-offset arrivals. On the 28787 picked arrivals on the whole OBS data set of the three presented models, 24446 picks are correctly reproduced which corresponds to $84.92 \%$ (see table in the supplementary material: misfits details for each phases).

The ray density shows the number of rays passing through a region of the model (Figure 5-B and in supplementary data). The ray density is twice higher along AN5 line compared to lines AN3 and AN1 due to a larger number of OBSs and a better quality of data. Nevertheless, the three models present a good ray coverage in their central and shallower parts and satisfying coverage in depth and on the sides of models.

The resolution factor (Figure 5-C) is calculated using the number of rays passing through a single node normalized by the number of rays passing through the layer corresponding to this node (Zelt and Smith 1992). Therefore, this factor depends on the number, the position of nodes and the lateral velocity variations in the model. Nodes with values greater than 0.5 are considered to be well resolved. Values lower than 0.5 correspond to insufficient resolution. Generally, these low resolution values correspond to the sides of velocity models. Shallow interfaces are not well constrained by turning waves from the OBS data however the geometry of these interfaces is very well constrained by MCS data, and velocities, by local reflected and refracted phases.

To additionally constrain our velocity models, gravity modeling was undertaken. The 2D velocity models were first converted to density models using an empirical law (Ludwig et al. 1970). These density models were then used to generate a predicted free air gravity anomaly (Zelt and Smith 1992). The predicted anomalies are then compared to free-air anomalies observed and derived from satellite altimetry (Smith and Sandwell 1997) (Figure 5-D). For the three profiles, predicted and observed gravity anomalies are in very good agreement indicating a good coherency of the velocity models with the gravimetric signal.

To conclude, the different methods of error analysis generally indicate, that the models are well constrained for sedimentary and crustal layers and for geometry of the subducting plate except on the edges of the models. On the other hand, and probably because of a complex abrupt geometry, the structure of layers underneath the Sombrero Basin is less well constrained. Also the velocity and thickness of the subducting oceanic crust are relatively poorly constrained due to the lack of reflected and refracted phases from this layer. 

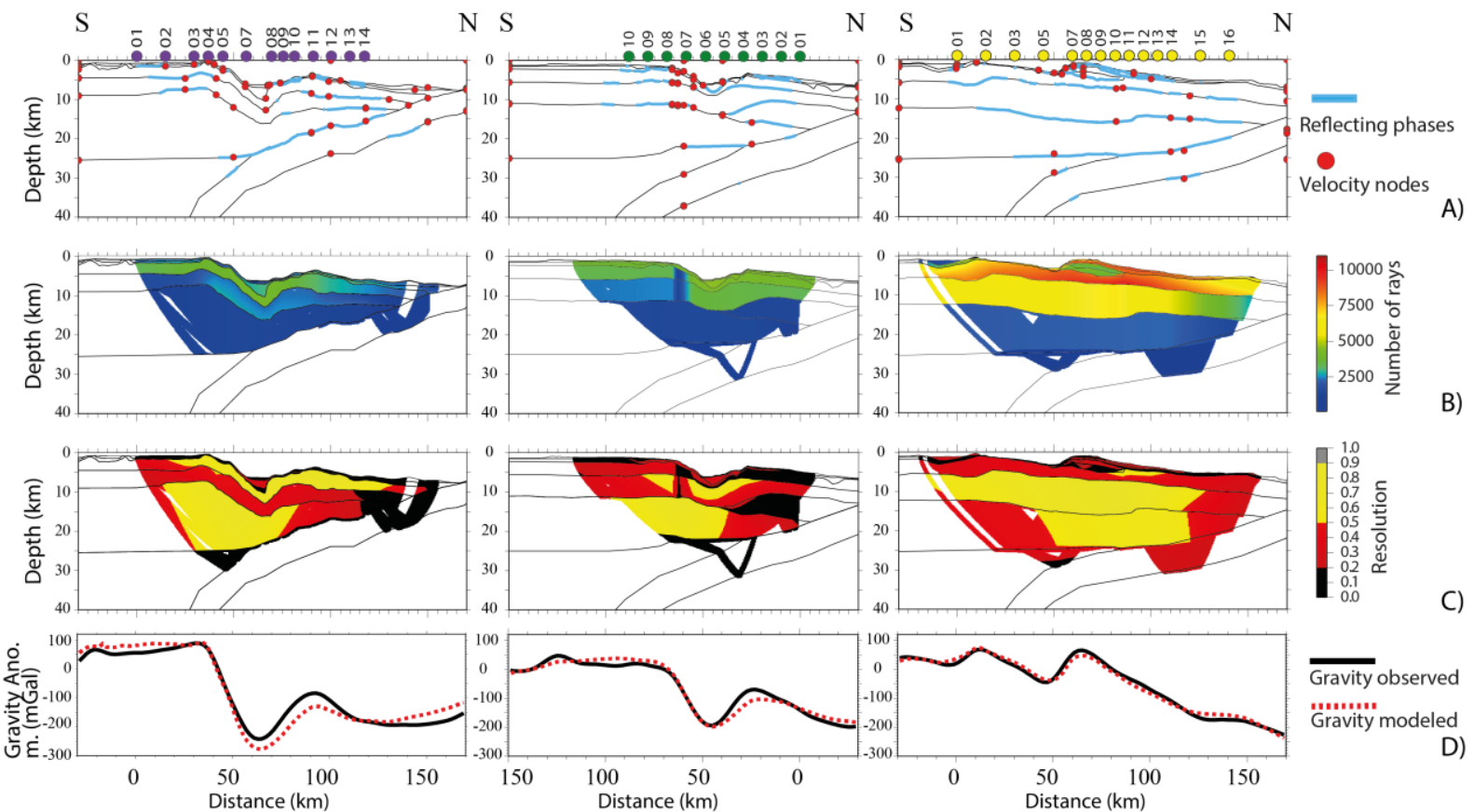

Gravity observed "Gravity" modeled

AN1 AN3

AN5

EV: 2

244 Figure 5: Resolution parameters for lines AN1, AN3 and AN5. (A) Interfaces constrain by reflecting phases are highlighted in blue. Red circles correspond to the position of velocity nodes. (B) Ray density. (C) Resolution parameter for velocity nodes. Grey and yellow areas are considered as well resolved (D) Results from gravity modeling. 

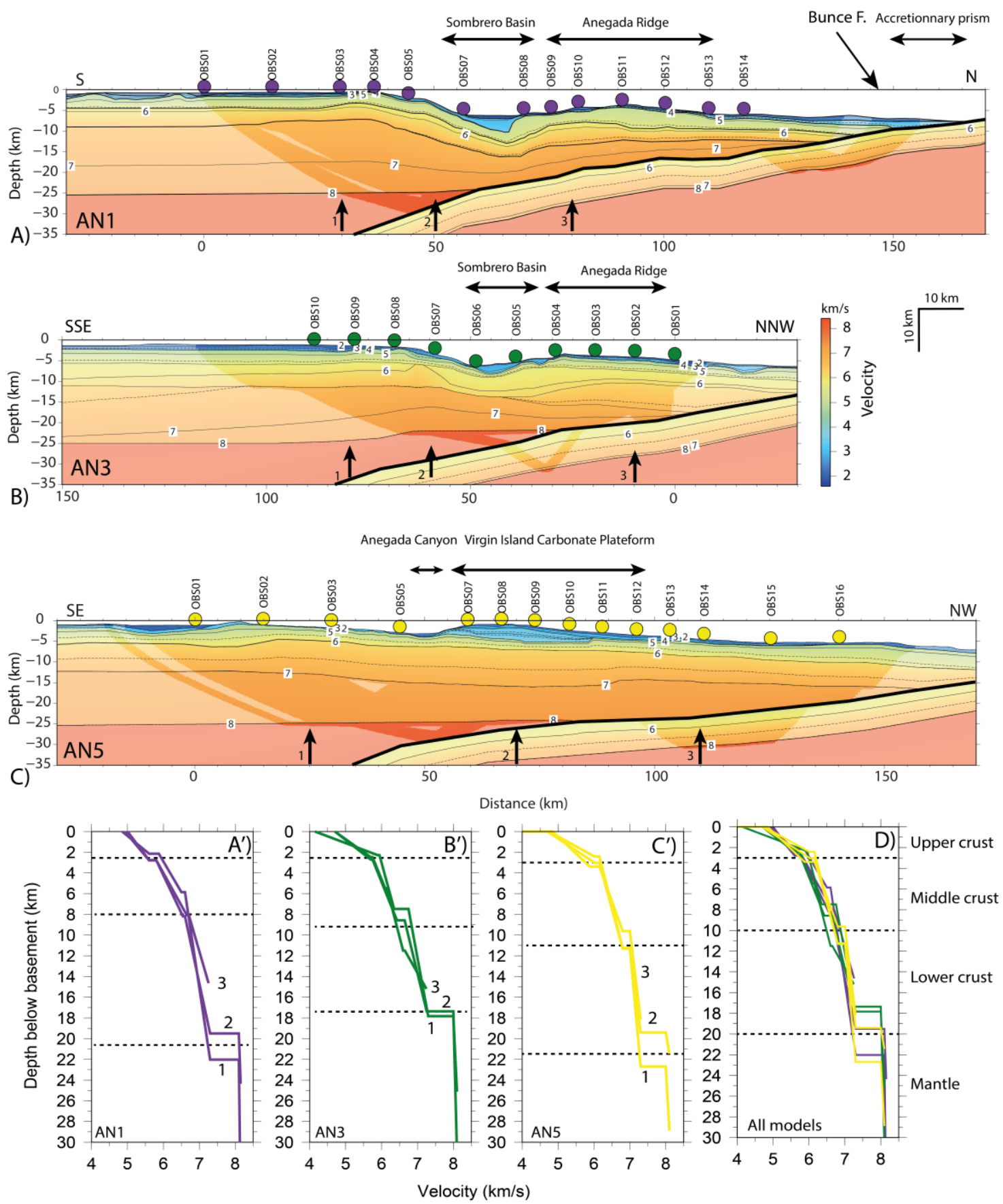

Figure 6: Final velocity models for lines AN1, AN3 and AN5 (A-B-C). Shaded areas are constrained by rays. Colored dots show location of OBSs. Velocity contours are drawn every $0.5 \mathrm{~km} / \mathrm{s}$. Thick lines depict limits of layers obtained from forward modelling and the bold one correspond to the top of the subducting plate. Vertical black arrows indicate positions of the $1 D$ velocity depth profiles from the top of the basement for each models $\left(A^{\prime}-B^{\prime}-C^{\prime}\right)$. (D) Compilation of every $1 D$ velocity depth profiles from the three models.

\section{Results}

The three final wide-angle velocity models (Figure 6-A-B-C) image the crust of the upper plate corresponding to the Caribbean plate and to the north, its overlying sedimentary layers as well as the incoming oceanic crust corresponding to the top of the subducting North American plate. 
The incoming oceanic crust dips with an angle of approximately $11^{\circ}$ for AN1 and AN3 and $6^{\circ}$ to $7^{\circ}$ for AN5 (Figure 6-A-B-C). Few refracted and reflected rays have been modeled through and at the bottom of the layer below the accretionary prism and the forearc (Figure 6-A-B-C). It images an approximately 7-km-thick subducting plate layer with velocities ranging from 5.5 to $7.1 \mathrm{~km} / \mathrm{s}$. Due to the lack of turning wave arrivals from the upper mantle, the velocities of the upper mantle of the subducting slab remain largely unresolved.

The models image low velocity $(1.8 \mathrm{~km} / \mathrm{s}$ to $3.5 \mathrm{~km} / \mathrm{s})$ layers on the top of the upper plate with an average thickness of $2 \mathrm{~km}$ and locally up to 5-km-thick. Between $\mathrm{km} 60$ to 70 model distance for $\mathrm{AN} 1$ and $\mathrm{km} 50$ to 60 model distance for AN3, the low velocity layer is asymmetric and reaches a thickness of $5 \mathrm{~km}$. Along line AN5, the low velocity layer, located between $\mathrm{km} 55$ to 85 model distance, over a 30-km-wide and 5-km-thick, has a velocity of $\sim 3.5 \mathrm{~km} / \mathrm{s}$. Moreover, line AN1 extends to the deformation front and delineates clearly a maximum 5-km-thick unit between model distances 150 to $165 \mathrm{~km}$ above the subducting plate (Figure 6-A-B-C), interpreted as the accretionary prism.

The velocity-depth (Vz) 1D profiles extracted beneath the sedimentary layers for models AN1, 3 and 5 (Figure 6-A'-B'-C') allow to identify 3 crustal layers. For the three models, the Moho of the upper crust is approximately at $25-\mathrm{km}$-depth. The crustal thickness decreases gradually towards the deformation front from $22 \mathrm{~km}$ to $15 \mathrm{~km}$ for AN1, from $18 \mathrm{~km}$ to $15 \mathrm{~km}$ for AN3 and from $23 \mathrm{~km}$ to $18 \mathrm{~km}$ for AN5. The mantle wedge appears to be located beneath the Sombrero Basin (AN1 and AN3) and beneath the Anegada Canyon (AN5). The upper crustal layer thickness ranges from 3 to $6 \mathrm{~km}$ with velocities from 4.70 to $6.00 \mathrm{~km} / \mathrm{s}$. The middle crustal layer thickness ranges from 5 to $9 \mathrm{~km}$ with velocities from $6.00 \mathrm{~km} / \mathrm{s}$ to $6.80 \mathrm{~km} / \mathrm{s}$. The lower crustal layer is characterized by thicknesses from 8 to $16 \mathrm{~km}$ and velocities increasing from $7.00 \mathrm{~km} / \mathrm{s}$ to $7.30 \mathrm{~km} / \mathrm{s}$ (Figure 6). 


\section{1. $\quad$ Nature and origin of the upper plate}
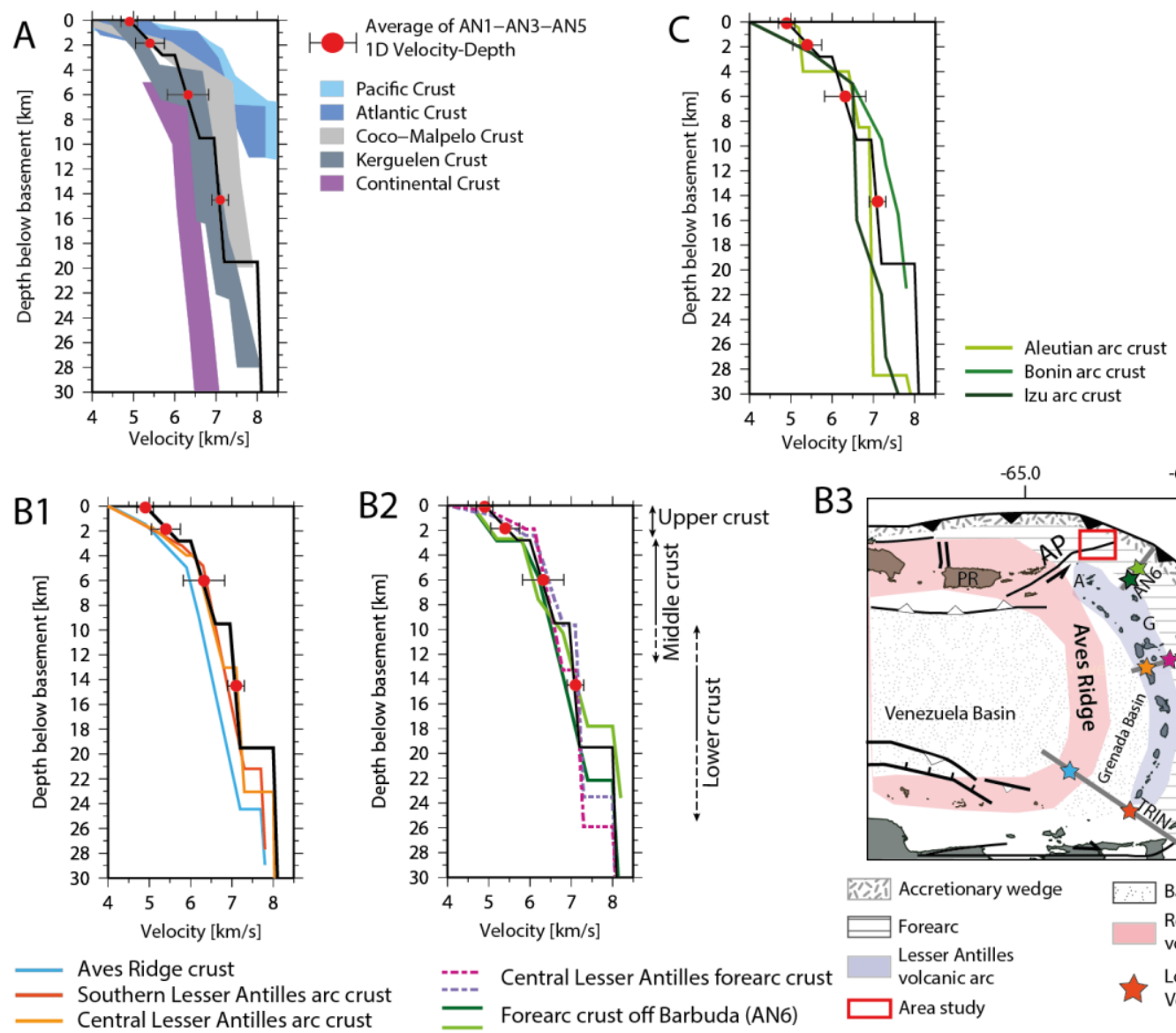

---- Central Lesser Antilles forearc crust

B3

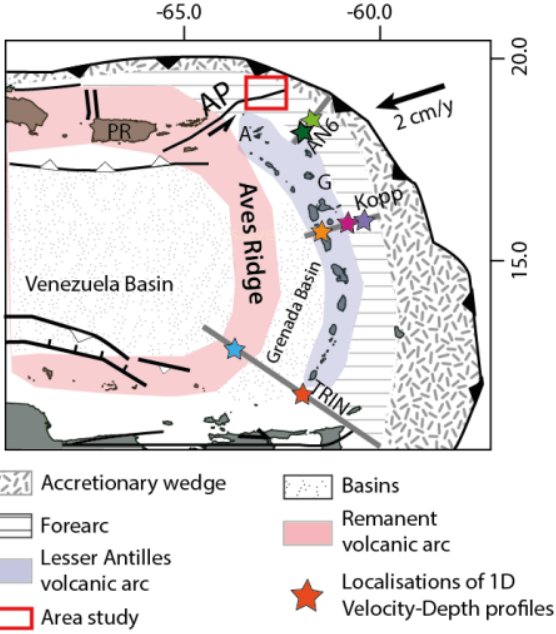

Figure 7: (A) Comparison between the average of $1 D$ velocity depth (Vz) profiles from models AN 1, 3 and 5 and various $1 D$ velocity depth profiles of oceanic crust (White et al. 1992) (blue shaded area), hot spot volcanic province (grey shaded area) (Operto and Charvis 1995; Marcaillou et al. 2006) and continental crust (purple shaded area) (Christensen and Mooney 1995). Comparison with 1D velocity depth profiles of the Lesser Antilles arc crust (B1), forearc crust (B2) (Christeson et al. 2008; Kopp et al. 2011; Klingelhoefer et al. 2016). Vz profiles

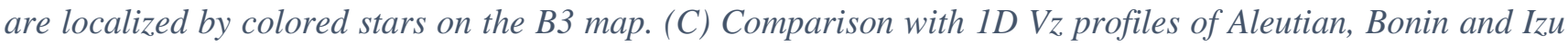
arc crusts (Shillington et al. 2004; Kodaira et al. 2010).

\subsubsection{Sedimentary layers}

Along every profile, layers with velocities ranging from 2 to $3.5 \mathrm{~km} / \mathrm{s}$ are likely to be of sedimentary origin. Three domains with such velocities are reported. The frontal part in line AN1 consists in a 15-km-thick accretionary prism limited southward by the Bunce Fault where the velocity suddenly rises up. This fault thus also corresponds with the backstop, which separates the accretionary prism from the forearc basement. In models AN1 and AN3, the asymmetric Sombrero Basin contains a thick sedimentary filling (Laurencin et al. 2017). In model AN5, a high-velocity $(3.5 \mathrm{~km} / \mathrm{s}) 3-\mathrm{km}$-thick layer corresponds with the northeastern part of Virgin Islands carbonate platform, which is consistent with limestone dredge 120D from cruise Arcante3 (Bouysse et al. 1985) located at km 50-distance in model AN5. 
Beneath the sedimentary layers, models show three crustal layers with velocities ranging from $4.7 \mathrm{~km} / \mathrm{s}$ to $7.1 \mathrm{~km} / \mathrm{s}$. In the upper crust, the velocity $(4.7$ to $6.0 \mathrm{~km} / \mathrm{s})$ is similar to the Izu-Bonin margin (Figure $7-\mathrm{C}$ ) and $\sim 0.5 \mathrm{~km} / \mathrm{s}$ higher than at the Central and Southern Lesser Antilles (Figure 7-B1). Thus it is consistent with a volcanoclastic, intrusive and extrusive rocks uppermost layer (Christeson et al. 2008; Kodaira et al. 2010; Kopp et al. 2011). The velocity variations probably depend on the fluid content, fracturing, porosity and alteration state of rocks. The velocities and thicknesses of the middle and lower layers are closely consistent with velocity models in the Central (Kopp et al. 2011) and Southern (Christeson et al. 2008) Lesser Antilles arc (Figure 7-B1) and for the interpreted arc-intermediate crustal layers at Aleutian and Izu-Bonin subduction zones (Figure 7-C), (Shillington et al. 2004; Kodaira et al. 2010). It supports the interpreted felsic to intermediate and gabbroic nature for the middle and lower layers respectively.

\subsubsection{Origin of crust}

The wide-angle-derived structure for the Northern Lesser Antilles margin shows strong similarities in velocities and thicknesses with the Kerguelen, Cocos-Malpelo, Aleutian and IzuBonin margins (Figure 7). However, for these margins the oceanic crust is interpreted as thickened mainly by subduction magmatism for the Aleutian and Izu-Bonin margin (Shillington et al. 2004; Kodaira et al. 2010) and by hotspot magmatism for the Kerguelen and CocosMalpelo provinces.

Previous velocity studies in the Central and Southern Lesser Antilles (Christeson et al. 2008; Kopp et al. 2011) and petrological studies of Hispaniola rocks samples and Caribbean plateau drilling samples (Kerr et al. 2003) suggest an oceanic basement thickened by hotspot magmatism. The similar velocity and thickness structures in the Northern Lesser Antilles and in Kerguelen and Cocos-Malpelo provinces (Figure 7-A), Southern and Central Lesser Antilles arc (Figure 7-B1) are consistent with this origin.

The dredged rocks, dated from Cretaceous to Paleocene, in the study area (Bouysse et al. 1985) suggest that the basement in the Northern Lesser Antilles is likely affected by the Cretaceous to Eocene 'Great Arc of the Caribbean' volcanism. This suggests a basement thickening by subduction volcanism in the Northern Lesser Antilles.

At the Aleutian and Izu-Bonin subduction zones, the thickening by subduction volcanism shows velocities $>7.3 \mathrm{~km} / \mathrm{s}$ at the base of the margin basement. This high-velocity layer is missing in the Northern Lesser Antilles models (Figure 7-C). Moreover, during the Eocene (Figure 1-D), the 'Great Arc of the Caribbean' volcanism likely migrated eastward to the Lesser Antilles arc. The Lesser Antilles volcanism has a very low magma production rates and does not mainly thickened the Lesser Antilles crust (e.g. Christeson et al. 2008), The subduction volcanism has possibly not contributed significantly to the margin basement thickening during the activity of the 'Great Arc of the Caribbean' either.

Thus, the Northern Lesser Antilles margin is consistent with an oceanic affinity crust mainly thickening by hotspot magmatism and to a lesser extent by the 'Great Arc of the Caribbean' volcanism. 

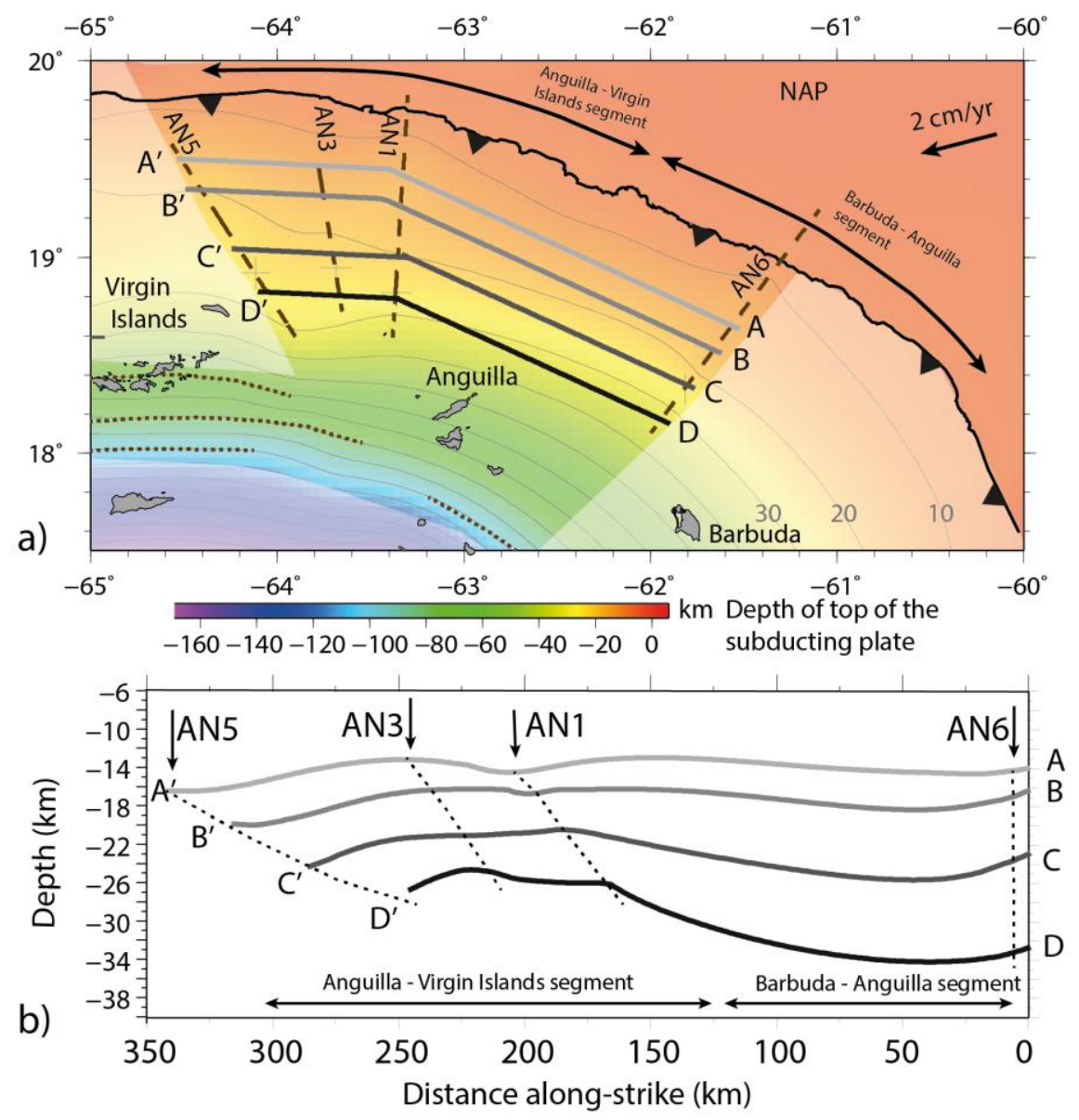

Figure 8: Depth of the top of the subducting plate (a) in $3 D(b)$ along $2 D$ along-strike sections $A A^{\prime}, B B^{\prime}, C C^{\prime}$, and $D D$ ' located at 35, 50,75, $105 \mathrm{~km}$ from the trench respectively. Black dotted lines AN1, AN3, AN5 (this study) and AN6 (Klingelhoefer et al. 2016) show the location for wide angle lines. Brown dotted lines are isohypocenter depths of earthquakes from McCann and Sykes (1984). NAP: North American Plate.

We use various datasets to determine the geometry of the subducting plate: (1) the location and depth of the top of the slab where it is constrained by reflected rays of the velocity models along lines AN1-3-5 (this study) and AN6 (Klingelhoefer et al. 2016), (2) the subduction earthquakes (McCann and Sykes 1984) under the volcanic islands (small dotted brown segments), and (3) the bathymetry of the trench and the plunging plate before subduction. Where unconstrained, the depth of the top of the slab is interpolated (Figure 8-a). This interpolation is unconstrained in areas located to the west of line AN5 and to the south-east of line AN6 that are beyond the scope of this study.

2D profiles parallel to the deformation front, $\mathrm{AA}$ ', BB', CC' and DD' show the along-strike variations in depth to the top of the slab at 35, 50, 75 and $105 \mathrm{~km}$ distance from the trench respectively (Figure 8-b). The slab depth at 35 and $50 \mathrm{~km}$ from the trench does not significantly vary along-strike (AA' and BB' in Figure $8 \mathrm{a}-\mathrm{b}$ ). In contrast, at $75 \mathrm{~km}$ from the trench, the slab is 26-km-deep offshore of the Barbuda-Anguilla margin segment and 20-km-deep offshore of 
the Anguilla-Virgin Islands margin segment ( $\mathrm{CC}^{\prime}$ in Figure 8-a-b). Moreover, at $105 \mathrm{~km}$, the slab depth varies from $36 \mathrm{~km}$ to $26 \mathrm{~km}$ between this two segments (DD' in Figure 8-a-b).

Thus, at shallow to intermediate depths (20 to $35 \mathrm{~km}$ ), beyond $75 \mathrm{~km}$ from the deformation front, the slab is $25 \%$ shallower beneath the Anguilla-Virgin Islands margin segment, than beneath the Barbuda Anguilla segment. Moreover, a tear fault in the slab between Puerto Rico and Virgin Islands possibly accommodates the shallow slab subduction under a curved margin by decreasing the slab dip to the east in the Northern Lesser Antilles (Ten Brink 2005; Meighan et al. 2013). This eastward shallowing of the slab beneath the Virgin Islands margin segment is strongly consistent with our results. The distance between models AN6 and AN1 does not allow us to constrain the precise shape of the slab related to the change in dip angle. Somewhere beneath Barbuda and Virgin Islands, a progressive large-scale flexure, a localized shear zone or a tear fault possibly accounts for this slab dip change. Either ways, this slab dip change, to the northeast of Barbuda and the Puerto Rico tear fault may allow a certain buoyancy degree for the slab that is shallower beneath the Anguilla-Virgin Islands margin segment.

\subsubsection{Origin of slab geometry variations}

In the following, we discuss several causes of variations in slab geometry and in particular in slab dips. Hikurangi, Japan and Northern Luzon subduction zones for example, also show complex slab geometries (Barker et al. 2009; Bautista et al. 2016). These authors conclude that chemical reactions, fluid release within the subducting plates as well as subduction of topographic highs mainly control the slab geometry. Seismic, heat flow and bathymetric data collected along the incoming North American plate show evidences for a large subducting basement patch of magmatic-poor mantellic-dominated rocks (Marcaillou et al. 2017). This dense and poorly resistant basement patch, subducting beneath the AntiguaAnguilla margin segment, possibly decreases the slab buoyancy.

Subducting buoyant ridges or seamounts may also result locally in a shallower slab as shown at numerous margins (e.g. Bautista et al. 2016) or reproduced in analogue models (e.g. Martinod et al. 2013). Seismic and bathymetric data highlight the extent of the Barracuda Ridge beneath the margin offshore of Antigua and Barbuda (Laigle et al. 2013). However, the Main Ridge (Figure 2) is a small-scale, thin and uncompensated topographic feature restricted to the Virgin Islands outer slope (Grindlay et al. 2005). The possible continuity between these ridges beneath the margin, as proposed by Mccann and Sykes (1984) is unclear. In any case, the subduction of a possibly buoyant ridge beneath the Antigua margin segment, where the slab is steep, or beneath the whole study area do not provide a convincing explanation for the northward shallowing of the slab.

North of the Caribbean, the $300000-\mathrm{km}^{2}$-area Bahamas Bank is a carbonate platform located on the North Atlantic plate and in collision at the Hispaniola trench. This collision possibly modifies the slab buoyancy offshore Hispaniola (e.g. Laó-dávila 2014) but is unlikely to interfere with the subduction system beneath the Anguilla-Virgin Islands margin.

The curved shape of the margin may imply geometrical complexities and discontinuities in the slab subduction. Larged scale, 3D numerical model of oblique subduction have shown slab folding that generates along-strike variations in slab dip and in upper plate topography (Cerpa et al. 2015). Moreover, modelling slab subduction beneath convex margins results in focussing the compressive strain in the upper plate toward the convexity axis generating margin uplift where the convexity climaxes (Bonnardot et al. 2008). These models highlight the influence of the plate boundary geometry and the subduction obliquity onto the slab dip angle and the deformation of the upper plate, that are strongly consistent with our results. At $18.5^{\circ} \mathrm{N}$ - 
$60.5^{\circ} \mathrm{W}$, to the northeast of Antigua-Barbuda, a kink in the subduction line shapes a convex plate boundary and results in a rapid increase of the subduction obliquity (Figure 2). To the north, the margin is spiked with numerous uplifted carbonnate platform and the slab shallows consistently with the expected slab folding due to subduction obliquity (Cerpa et al. 2015) and the compressive strain foccusing toward the convexity axis (Bonnardot et al. 2008). These consistencies suggest that the shallower slab beneath the Anguilla-Virgin Islands margin segment observed in wide-angle data is related to the margin convexity and the subduction obliquity.

\subsubsection{Tectonic partitioning and interplate coupling}

Varying geometry of subduction interface possibly controls variations in interplate seismic coupling, seismogenesis and margin tectonic deformation, in subduction zones as proposed in Hikurangi (e.g. Barker et al. 2009), North Chile (e.g. Boutelier and Oncken 2010) and Japan (e.g. Ito et al. 2009).

On a large scale, geodetic data suggest that the Lesser Antilles margin is only partially coupled between Barbuda and Virgin Islands (Manaker et al. 2008; Symithe et al. 2015). However, in subduction zones, structural heterogeneities possibly generate local variations in subduction interface properties and interplate seismic coupling that can be documented with dense local GPS deployments (e.g. Marcaillou et al. 2016). Thus, the slab shallowing may locally increase the interplate seismic coupling beneath the Anguilla-Virgin Islands segment. For the Northern Lesser Antilles no mega-thrust earthquake cycle has been detected yet. Thus, despite local variation in seismic coupling, the accumulation of stress at the subduction interface increases very slowly and/or a large part is relaxed by the deformations observed on the upper plate margin as proposed by Manaker et al. (2008) and Symithe et al. (2015).

In Northern Lesser Antilles, the earthquakes with thrust focal mechanism ( $\mathrm{Mw}>3.5$ from CMT catalog, since 1976) and shallow, 0-40-km-depth, earthquakes (PDE/NEIC catalog, $\mathrm{Mw}>5$, since 1900) are more numerous beneath the Anguilla-Virgin Islands margin segment than beneath the Barbuda-Anguilla margin segment (Figure 9-b). Mccann and Sykes (1984) propose that this seismic heterogeneity is controlled by local tectonic complexity related to subducting reliefs as the Main Ridge (Figure 2). This northwestward increase in seismicity raises the question of a possible relation with the slab northward shallowing. Moreover, at shallow depths $(18-30 \mathrm{~km})$, the slab shallowing may increase the length of the brittle interface between the upper and the downgoing crusts. This may increase the length of the seismogenic zone and the subduction seismic activity.

The major EW-trending strike-slip Anegada Passage accommodates at least a part of the tectonic partitioning due to the plate convergence obliquity (Laurencin et al. 2017). It is noteworthy that the Anegada Passage entails the margin above the area where the slab dip decreases (Figure 9-a-b) which raises the question of a possible relation between the slab northward shallowing and the onset of this partitioning. 3D models of convex subduction zones point out that curved margin zones focus compressive strain and uplifts and are thus preferential zones for strike-slip faults initiation (Bonnardot et al. 2008). Thus, we propose that the slab shallowing under Anguilla-Virgin Islands segment increases locally the transfer of interplate shear stresses to the overriding plate and also favors partitioning deformation. 


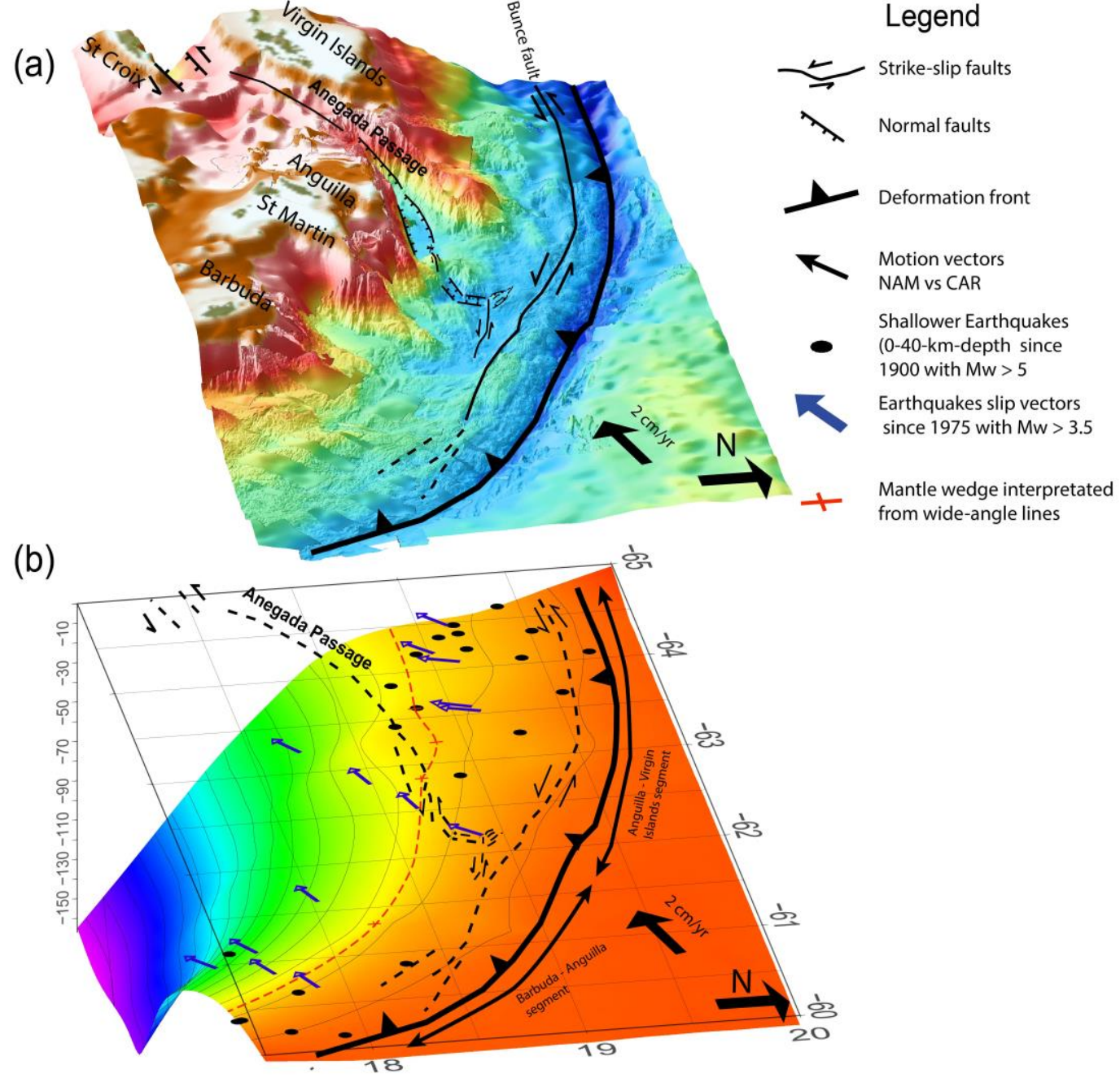

438 Figure 9: (a) 3D view of the Northern Lesser Antilles bathymetry and the interpreted tectonic 439 deformation pattern within the upper plate (Laurencin et al. 2017) (b) Top of the subducting plate with 440 projection of some margin tectonic deformations features (dotted black lines), shallower earthquakes (0-40-km-depth) since 1900 with Mw > 5 (black circles), subducting earthquakes slip vectors since 1976 from CMT global catalog $(M w>3.5)$, (blue arrows) and the localization of the mantle wedge (dotted red line)

\section{6. Conclusions}

445 Wide-angle models across the Northern Lesser Antilles forearc provide new insights into the geometry of the subducting North America plate, the nature and origin of the northeastern upper caribbean margin and the consequences for tectonic deformations and seismogenesis:

448 1) The velocity and thickness structure across the Northern Lesser Antilles margin is consistent with an oceanic affinity crust over-thickened by hotspot magmatism and to a lesser extent by the subdcution volcanism of the 'Great Arc of the Caribbean'.

451 2) The depth to the top of the subducting plate is $25 \%$ shallower under the Anguilla-Virgin Islands segment than under the Barbuda-Anguilla segment. This slab shallowing is possibly related to the effects of the increasing subduction obliquity of the North America Plate beneath the convex Northern Lesser Antilles margin. 
455 3) We propose that the shallower slab under the Anguilla-Virgin Islands segment locally 456 increases the interplate shear stress favoring the tectonic partitioning observed in the Anegada 457 Passage. This slab shallowing may also locally increase the interplate coupling, even though it 458 is low on a large scale, which is consistent with the northward increasing number of 459 earthquakes.

\section{Acknowledgments}

461 We thanks the Captain and the crew of the RVs L'Atalante and Pourquoi Pas? We are indebted 462 to the Genavir Technicians for bathymetry processing, the successful completion of the seismic 463 acquisition and to the scientific crew for the pre-processing undertaken onboard. We 464 acknowledge financial support from Region Bretagne for PhD fellowship of M. Laurencin. We 465 thank Labex MER, INSU and Antilles University of Guadeloupe Island for the partly financing 466 cruises. Most of the figures were drafted using GMT and Qgis software. All data of the 467 ANTITHESIS cruises are available on demand at SISMER (www.ifremer.fr/sismer/). 
Auffret, Y., Pelleau, P., Klingelhoefer, F., Géli, L., Crozon, J., Lin, J., and Sibuet, J-C. 2004. MicrOBS : a new generation of ocean bottom seismometer. First Break 22: 41-47.

Barker, D. H. N., Sutherland, R., Henrys, S., and Bannister, S. 2009. Geometry of the Hikurangi subduction thrust and upper plate, North Island, New Zealand. Geochemistry, Geophysics, Geosystems 10: 1-23. doi:10.1029/2008GC002153.

Bautista, B. C., Bautista, M. L. P., Oike, K., Wu, F. T., and Punongbayan, R. S. 2016. A new insight on the geometry of subducting slabs in Northern Luzon, Philippines in northern Luzon, Philippines. Tectonics 339: 279-310. doi:10.1016/S0040-1951(01)00120-2.

Van Benthem, S., Govers, R., Spakman, W., and Wortel, R. 2013. Tectonic evolution and mantle structure of the Caribbean. Journal of Geophysical Research: Solid Earth 118: 3019-3036. doi:10.1002/jgrb.50235.

Bernard, P., and Lambert, J. 1988. Subduction and seismic hazard in the Northern Lesser Antilles : Revision of the historical seismicity. Bulletin of the Seismological Society of America 78: 1965-1983.

Bonnardot, M., Hassani, R., Tric, E., and Ruellan, E. 2008. Effect of margin curvature on plate deformation in a 3-D numerical model of subduction zones. Geophysical Journal International 173: 1084-1094. doi:10.1111/j.1365-246X.2008.03752.x.

Boschman, L. M., Van Hinsbergen, D. J. J., Torsvik, T. H., Spakman, W., and Pindell, J. L. 2014. Earth-Science Reviews Kinematic reconstruction of the Caribbean region since the Early Jurassic. Earth Science Reviews 138. Elsevier B.V.: 102-136. doi:10.1016/j.earscirev.2014.08.007.

Boutelier, D. A., and Oncken, O. 2010. Role of the plate margin curvature in the plateau buildup : Consequences for the central Andes. Journal of Geophysical Research 115: 1-17. doi:10.1029/2009JB006296.

Bouysse, P., Andreieff, P., Richard, M., Baubron, J. C., Mascle, A., Maury, R. C., and Westercamp, D. 1985. Aves Swell and northern Lesser Antilles Ridge: rock-dredging results from ARCANTE 3 cruise. In Géodynamique des caraibes. Symposium, 65-76.

Bouysse, P., and Westercamp, D. 1990. Subduction of Atlantic aseismic ridges and Late Cenozoic evolution of the Lesser Antilles island arc. Tectonophysics. doi:10.1016/0040-1951(90)90180-G.

Ten Brink, U. 2005. Vertical motions of the Puerto Rico Trench and Puerto Rico and their cause. Journal of Geophysical Research 110: 1-16. doi:10.1029/2004JB003459.

Ten Brink, U., Danforth, W., Polloni, C., Andrews, B., Llanes, P., Smith, S., Parker, E., and Uozumi, T. 2004. New seafloor map of the Puerto Rico trench helps assess earthquake and tsunami hazards. Eos, Transactions American Geophysical Union 85: 349-360. doi:10.1029/2004EO370001.

Cerpa, N.G., Araya, R., Gerbault, M., and Hassani, R. 2015. Relationship between slab dip and topography segmentation in an oblique subduction zone: Insights from numerical modeling. Geophysical Research Letters 42: 1-10. doi:10.1002/2015GL064047.

Christensen, N. I., and Mooney, W. D. 1995. Seismic velocity structure and composition of the continental crust: A global view. Journal of Geophysical Research 100: 9761-9788. doi:10.1029/95JB00259.

Christeson, G. L., Mann, P., Escalona, A., and Aitken, T. J. 2008. Crustal structure of the Caribbean - Northeastern South America arc-continent collision zone. Journal of Geophysical Research 113: 1-19. doi:10.1029/2007JB005373.

DeMets, C., Jansma, P., Mattioli, G., Dixon, T. H., Farina, F., Bilham, R., Calais, E., and Mann, P. 2000. GPS geodetic constraints on Caribbean-North America plate motion. Geophysical Research Letters 27: 437-440.

Feuillet, N., Beauducel, F., and Tapponnier, P. 2011. Tectonic context of moderate to large historical earthquakes in the Lesser Antilles and mechanical coupling with volcanoes. Journal of Geophysical Research 116: 126. doi:10.1029/2011JB008443.

Fitch, T J. 1972. Plate Convergence, Transcurrent Faults, and Internal Deformation Adjacent to Southeast Asia and the Western Pacific. Journal of Geophysical Research 77: 4432-4460.

Grindlay, N. R., Mann, P., Dolan, J. F., and Van Gestel, J. P. 2005. Neotectonics ans subsidence of the northern Puerto Rico-Virgin Islands margin in response to the oblique subduction of high-standing ridges. Edited by Paul Mann. Geological Society of America Special Papers 385: 31-60.

Hayes, G. P., Wald, D. J., and Johnson, R. L. 2012. Slab1.0 : A three-dimensional model of global subduction zone geometries. Journal of Geophysical Research 117: 1-15. doi:10.1029/2011JB008524.

Ito, Tanio., Kojima, Yuji., Kodaira, Shuichi., Sato, Hiroshi., Kaneda, Yoshiyuki., Iwasaki, Takaya., Kurashimo, Eiji., Tsumura, Noriko., Fujiwara, Akira., Miyauchi, Takahiro., Hirata, Naoshi., Harder, Steven., Sato, Takeshi., and Ikawa, Takeshi. 2009. Tectonophysics Crustal structure of southwest Japan, revealed by the integrated seismic experiment Southwest Japan 2002. Tectonophysics 472. Elsevier B.V.: 124-134. doi:10.1016/j.tecto.2008.05.013. 
James, K. H. 2009. In situ origin of the Caribbean: discussion of data. Geological Society, London, Special Publications 328: 77-125. doi:10.1144/SP328.3.

Jany, I., Scanlon, K. M., and Mauffret, A. 1990. Geological interpretation of combined Seabeam, Gloria and seismic data from Anegada Passage (Virgin Islands, north Caribbean). Marine Geophysical Researches 12: 173-196. doi:10.1007/BF02266712.

Jolly, Wayne T., Lidiak, Edward G., and Dickin, Alan P. 2008. Bimodal volcanism in northeast Puerto Rico and the Virgin Islands ( Greater Antilles Island Arc ): Genetic links with Cretaceous subduction of the midAtlantic ridge Caribbean spur. doi:10.1016/j.lithos.2007.10.008.

Kerr, A.C., White, R.V., Thompson, P. M. E., and Saunders, A.D. 2003. No oceanic plateau-no Caribbean plate? The seminal role of an oceanic plateau in Caribbean plate evolution. In The Circum-Gulf of Mexico and the Caribbean: Hydrocarbon habitats, basin formation, and plate tectonics: AAPG Memoir 79, C. Bartoli, 126168.

Klingelhoefer, F., Laurencin, M., Marcaillou, B., Benabdellouahed, M., Graindorge, D., Maury, T., Biari, Y., Evain, M., Chang, E., Scalabrin, C., and Lebrun, J.-F. 2016. Relations between the deep crustal structure and fluid escape structures at the Lesser Antilles Island arc. Poster AGU.

Kodaira, S., Noguchi, N., Takahashi, N., Ishizuka, O., and Kaneda, Y. 2010. Evolution from fore-arc oceanic crust to island arc crust: A seismic study along the Izu-Bonin fore arc. Journal of Geophysical Research 115Kodaira: 1-20. doi:10.1029/2009JB006968.

Kopp, H., Weinzierl, W., Becel, A., Charvis, P., Evain, M., Flueh, E. R., Gailler, A., Galve, A., Hirn, A., Kandilarov, A., Klaeschen, D., Laigle, M., Papenberg, C., Planert, L., and Roux, E. 2011. Deep structure of the central Lesser Antilles Island Arc: Relevance for the formation of continental crust. Earth and Planetary Science Letters 304. Elsevier B.V.: 121-134. doi:10.1016/j.eps1.2011.01.024.

Laigle, M., Becel, A., de Voogd, B., Sachpazi, M., Bayrakci, G., Lebrun, J.-F., Evain, M., and Group, the "Thales was Right" Seismic Reflection working. 2013. Along-arc segmentation and interaction of subducting ridges with the Lesser Antilles Subduction forearc crust revealed by MCS imaging. Tectonophysics 603: 32-54. doi:10.1016/j.tecto.2013.05.028.

Laó-dávila, D. 2014. Collisional zones in Puerto Rico and the northern Caribbean. Journal of South American Earth Sciences 54. Elsevier Ltd: 1-19. doi:10.1016/j.jsames.2014.04.009.

Laurencin, M., Marcaillou, B., Graindorge, D., Klingelhoefer, F., Lallemand, S., Laigle, M., and Lebrun, J.F. 2017. The polyphased tectonic evolution of the Anegada Passage in the northern Lesser Antilles subduction zone. Tectonics 36: 17. doi:10.1002/2017TC004511.

López, A. M., Stein, S., Dixon, T., Sella, G., Calais, E., Jansma, P., Weber, J., and LaFemina, P. 2006. Is there a northern Lesser Antilles forearc block? Geophysical Research Letters 33: 2-5. doi:10.1029/2005GL025293.

Ludwig, W. J., Nafe, J. E., and Drake, C. L. 1970. Seismic refraction. The sea 4: 53-84.

Manaker, D. M., Calais, E., Freed, A. M., Ali, S. T., Przybylski, P., Mattioli, G., Jansma, P., Prépetit, C., and De Chabalier, J. B. 2008. Interseismic plate coupling and strain partitioning in the Northeastern Caribbean. Geophysical Journal International 174: 889-903. doi:10.1111/j.1365-246X.2008.03819.x.

Mann, P., Grindlay, N. R., and Abrams, L. J. 2005. Neotectonics of southern Puerto Rico and its offshore margin. Geological Society of America Special Papers 385: 173-214. doi:10.1130/0-8137-2385-X.173.

Marcaillou, B., Charvis, P., and Collot, J.-Y. 2006. Structure of the Malpelo Ridge (Colombia) from seismic and gravity modelling. Marine Geophysical Researches 27: 289-300. doi:10.1007/s11001-006-9009-y.

Marcaillou, B., Collot, J.-Y., Ribodetti, A., Mahamat, A.-A., and Alvarado, A. 2016. Seamount subduction at the North-Ecuadorian convergent margin: Effects on structures, inter-seismic coupling and seismogenesis. Earth and Planetary Science Letters 433. Elsevier B.V.: 146-158. doi:10.1016/j.epsl.2015.10.043.

Marcaillou, B., and Klingelhoefer, F. 2013. ANTITHESIS-1-Leg1 Cruise, RV L'Atalante. Cruises Report. doi:10.17600/13010070.

Marcaillou, B., Klingelhoefer, F., Laurencin, M., Biari, Y., Graindorge, D., Lebrun, J.-F., Laigle, M., and Lallemand, S.E. 2017. The Subduction of an Exhumed and Serpentinized Magma-Poor Basement Beneath the Northern Lesser Antilles Reveals the Early Tectonic Fabric at Slow-Spreading Mid-Oceanic Ridges. In T31D-0656. AGU Fall Meeting. New Orleans.

Martinod, J., Guillaume, B., Espurt, N., Faccenna, C., Funiciello, F., and Regard, V. 2013. Tectonophysics Effect of aseismic ridge subduction on slab geometry and overriding plate deformation: Insights from analogue modeling. Tectonophysics 588. Elsevier B.V.: 39-55. doi:10.1016/j.tecto.2012.12.010.

McCaffrey, R. 1992. Oblique plate convergence, slip vectors, and forearc deformation. Journal of Geophysical Research. doi:10.1029/92JB00483.

McCann, W. R., Nishenko, S. P., Sykes, L. R., and Krause, J. 1979. Seismic gaps and plate tectonics: Seismic potential for major boundaries. Pure and Applied Geophysics PAGEOPH 117: 1082-1147. 
doi:10.1007/BF00876211.

McCann, W. R., and Sykes, L. R. 1984. Subduction of Aseismic Ridges beneath the Caribbean Plate : implications for the tectonics and seismic potential of the northeastern caribbean. Journal of Geophysical Research 89: 4493-4519.

Meighan, H. E., Pulliam, J., Ten Brink, U., and Lõpez-Venegas, A. M. 2013. Seismic evidence for a slab tear at the Puerto Rico Trench. Journal of Geophysical Research: Solid Earth 118: 2915-2923. doi:10.1002/jgrb.50227.

Meschede, M., and Frisch, W. 1998. A plate-tectonic model for the Mesozoic and Early Cenozoic history of the Caribbean plate. Tectonophysics 296: 269-291. doi:10.1016/S0040-1951(98)00157-7.

Neill, I., Kerr, A. C., Hastie, A. R., Stanek, K.-P., and Millar, I. L. 2011. Origin of the Aves Ridge and DutchVenezuelan Antilles: interaction of the Cretaceous "Great Arc" and Caribbean-Colombian Oceanic Plateau? Journal of Geological Society, London 168: 333-347. doi:10.1144/0016-76492010-067.

Operto, S., and Charvis, P. 1995. Kerguelen Plateau: a volcanic passive margin fragment? Geology 23: 137-140. doi:10.1130/0091-7613.

Pindell, J. L., and Kennan, L. 2009. Tectonic evolution of the Gulf of Mexico, Caribbean and northern South America in the mantle reference frame: an update. Geological Society, London, Special Publications 328: 1-55. doi:10.1144/SP328.1.

Reid, J., Plumley, P., and Schellekens, J. 1991. Paleomagnetic evidence for late miocene counterclockwise rotation of north coast carbonate sequence, Puerto Rico. Geophysical Research Letters 18: 565-568.

Schellart, W. P., Freeman, J., Stegman, D. R., Moresi, L., and May, D. 2007. Evolution and diversity of subduction zones controlled by slab width. Nature 446: 1-4. doi:10.1038/nature05615.

Shillington, D. J., Holbrook, W. S., Kelemen, P. B., and Hornbach, M. J. 2004. Composition and structure of the central Aleutian island aShillington, Donna J., Holbrook, W Steven., Kelemen, Peter B., and Hornbach, Matthew J. 2004. Composition and structure of the central Aleutian island arc from arc-parallel wide-angle seismic data. Geochemistry, Geophysics, Geosystems 5: 32. doi:10.1029/2004GC000715.

Smith, W. H. F., and Sandwell, D. T. 1997. Global Sea Floor Topography from Satellite Altimetry and Ship Depth Soundings. Science 277: 1956-1962.

Symithe, S., Calais, E., De Chabalier, J. B., Robertson, R., and Higgins, M. 2015. Current Block Motions and Strain Accumulation on Active Faults in the Caribbean. Journal of Geophysical Research.

Syracuse, E. M., and Abers, G. A. 2006. Global compilation of variations in slab depth beneath arc volcanoes and implications. Geochemistry, Geophysics, Geosystems 7. Wiley Online Library.

White, R. S., Mckenzie, D. N., and Nions, K. O. 1992. Oceanic crustal thickness from seismic measurements and rare earth element inversions. Journal of Geophysical Research 97: 19,683-19,715.

Zelt, C. A., and Smith, R. B. 1992. Seismic traveltime inversion for 2 D crustal velocity structure. Geophysical Journal International 108: 16-34. doi:10.1111/j.1365-246X.1992.tb00836.x. 
621 The quality control and the binning of the MCS data were performed on board using 622 QCSispeed® (Antithesis 1) and SolidQC® (Antithesis 3) developed by Ifremer and the 623 processing was performed using GEOCLUSTER® and GEOVATION®. The processing sequence includes: a $4 \mathrm{~ms}$ data sampling, a band-pass filtering (2-7-60-80 Hz), a FK filtering in order to reduce linear noises, amplitude attenuation for noisy traces due for example to streamer birds, a predictive deconvolution to improve the image resolution, velocity analysis and Normal Move-Out (NMO) correction, external mute to remove the direct and refracted waves and reduce the far offset reflection stretching, internal mute to reduce the primary multiple amplitude, velocity stack. As the acquisition is at deep water depth, we applied a post stack (f,k) migration at constant velocity of $1520 \mathrm{~m} / \mathrm{s}$.

\section{Comparison between MCS and WAS lines}

632 For modelling the AN1 velocity model, the sedimentary interfaces, the top of the crust and the 633 interplate were interpreted from the reflection seismic profiles and converted in kilometers 634 helping to build the model. For AN3 and AN5 models, MCS profiles were acquired during 635 Antithesis 3, thus 2 years after wide-angle data. Thus, we simply checked that the velocity 636 model interfaces is coincided with the interpretation of the following profiles (Figure a).

637

638 


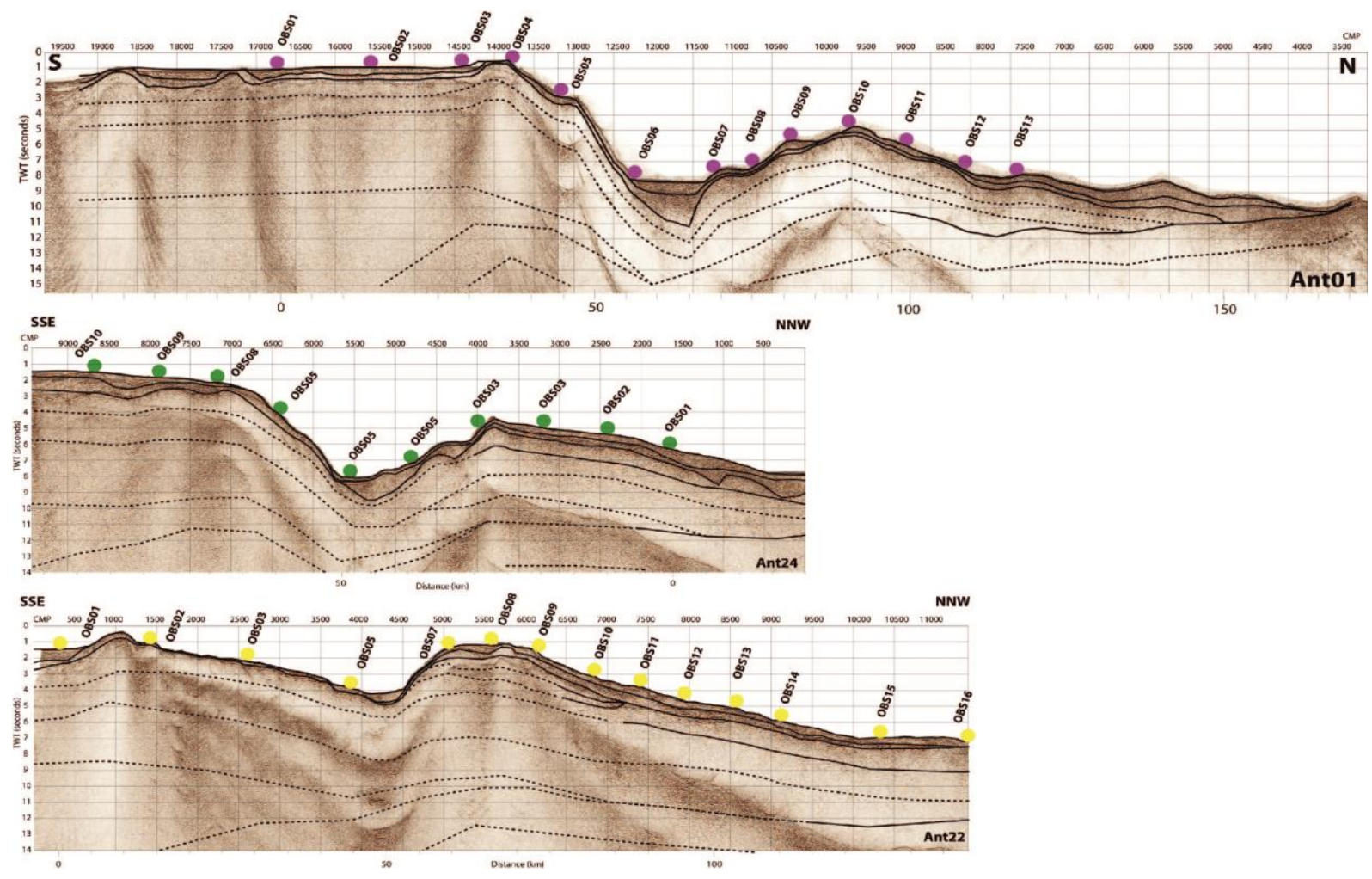

Figure a: Reflection seismic lines coincident with velocity model interfaces. The solid lines correspond in interfaces of the wide-angle model that were interpreted on seismic reflection data and the dotted line is only interfaces of the model In OBS locations are indicated by colored circles.

\section{Resolution, RMS and $\mathrm{Chi}^{2}$}

642 A total of 24419 points were modelled (Figure b) for a total of 28787 pointed arrivals, then 643 approximately $85 \%$ (Table 1).

\begin{tabular}{|c|c|c|c|}
\hline profile & number of modelised data & number of picked data & rate \\
\hline AN1 & 6184 & 7788 & 79,40 \\
\hline AN3 & 6837 & 8340 & 81.98 \\
\hline AN5 & 11425 & 12659 & 90.25 \\
\hline total & 24446 & 28787 & 84.92 \\
\hline
\end{tabular}

Table 1 : number of picked travel times and number arrivals predicted from the three velocity models 
Figure b: 1 on 5 raypath for each profile are presented on each profile 1.
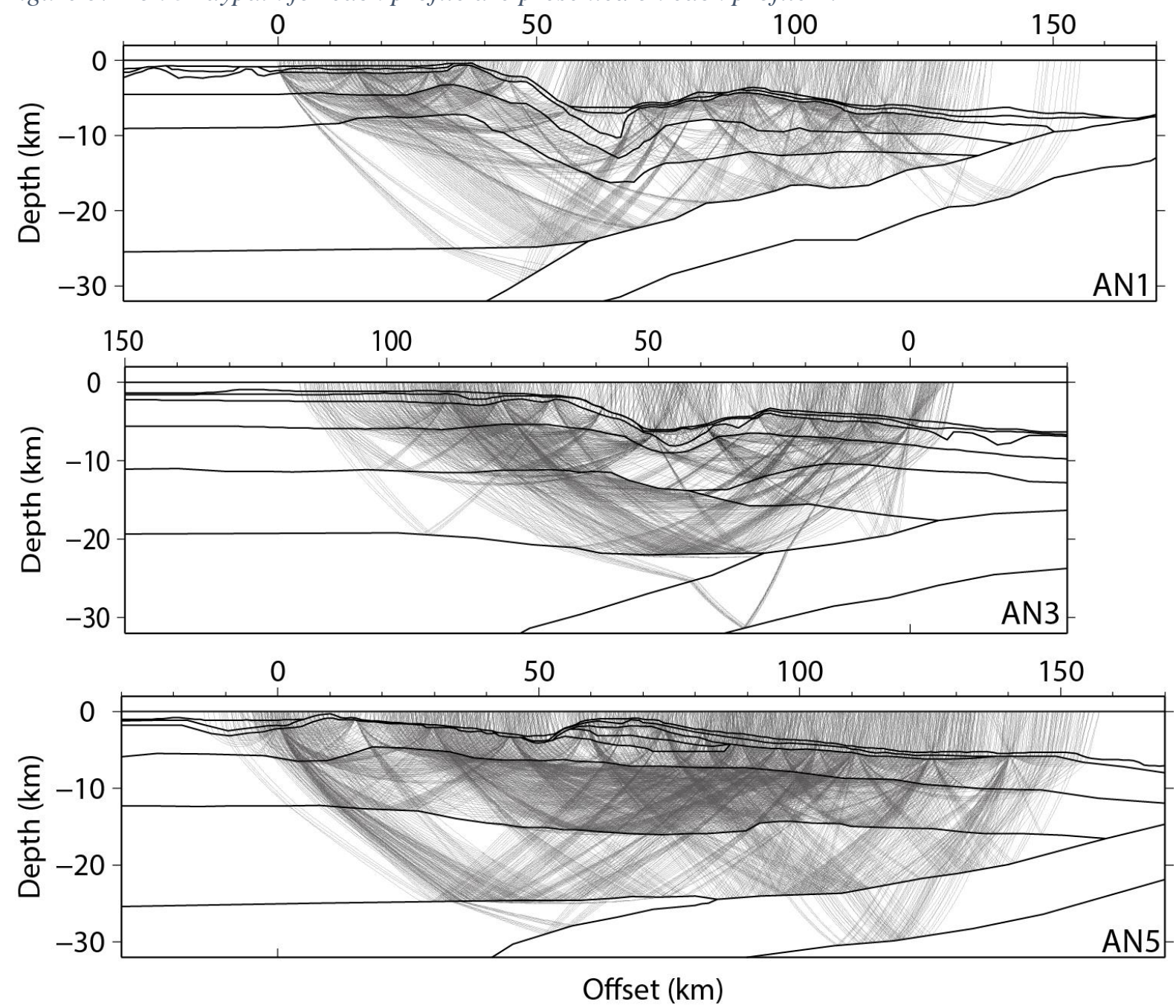

649 The pointed phases depend on user and data quality. When the source-to-receiver distance 650 increases, the arrival phases are generally less accurate due to noise increasing. Indeed, for 651 larger offsets, it is easier to observe the first oscillation of the lower frequency bubble than the 652 first peak (high frequency). Thus, an uncertainty is proposed by the user for each phases pointed 653 according to its accuracy. This uncertainty can vary between $60 \mathrm{~ms}$ for the direct wave and 200 $654 \mathrm{~ms}$ for larger offsets (Table 2).

655 We evaluate the resolution of velocity model by the root mean square error (RMS). For AN1 656 profile, the RMS error is $0.158 \mathrm{~ms}$; for AN3; $0.167 \mathrm{~ms}$ and for AN5; $0.150 \mathrm{~ms}$. This parameter 657 is also calculated for each phase, the RMS error value varies between $0.060 \mathrm{~ms}$ for the direct 658 wave and $0.291 \mathrm{~ms}$ for the deeper phases (Table 2).

659 Another value is calculated by the formula below, the $\mathrm{Chi}^{2}$, which links the difference between 660 the observed and calculated arrival times, the number of pointed phases and the pointed 661 uncertainties (Table 2).

$$
C h i^{2}=\frac{1}{N} \sum_{N}^{i}\left(\frac{\operatorname{tcalc}(i)-\operatorname{tcalc}(i)}{\sigma(\mathrm{i})}\right)^{2}
$$

With, 
$664 N$ : calculated arrival number; $\operatorname{tobs}(i)$ : pointed arrival times; tcalc $(i)$ : calculated arrival times 665 et $\sigma(\mathrm{i}):$ pointed uncertainty.

666

667

The best constrained model corresponds to the lowest RMS, the highest modelled peak number 668 and the $\mathrm{Chi}^{2}$ closest to 1 (Table 2).

669 


\begin{tabular}{|c|c|c|c|c|c|c|c|}
\hline $\begin{array}{l}\text { AN1 } \\
\text { Phases }\end{array}$ & $\begin{array}{l}\text { Number of } \\
\text { data }\end{array}$ & RMS (s) & $\mathrm{Chi}^{2}$ & $\begin{array}{l}\text { AN3 } \\
\text { Phases }\end{array}$ & $\begin{array}{l}\text { Number of } \\
\text { data }\end{array}$ & $\begin{array}{l}\text { RMS } \\
\text { (s) }\end{array}$ & $\mathrm{Chi}^{2}$ \\
\hline Direct & 603 & 0,084 & 1.974 & Direct & 622 & 0,57 & 0910 \\
\hline PS1 & 74 & 0,159 & 2.555 & PS1 & 15 & 0,081 & 0.70 \\
\hline Ps1P & 145 & 0,126 & 1.607 & Ps1P & 391 & 0,091 & 0.827 \\
\hline PS2 & 89 & 0,108 & 1.186 & PS2 & 85 & 0,099 & 0.998 \\
\hline Ps2P & 221 & 0,095 & 0.909 & Ps2P & 266 & 0,061 & 0.371 \\
\hline aPC1 & 1469 & 0,119 & 0.631 & PC1 & 954 & 0,098 & 0.956 \\
\hline Pc1P & 498 & 0,133 & 0.782 & Pc1P & 474 & 0,121 & 1.467 \\
\hline PC2 & 1042 & 0,182 & 1.482 & PC2 & 1419 & 0,216 & 2.084 \\
\hline Pc2P & 521 & 0,189 & 1.596 & Pc2P & 770 & 0,18 & 1.445 \\
\hline PC3 & 447 & 0,182 & 1.472 & PC3 & 104 & 0,283 & 3.593 \\
\hline Pc3P & 959 & 0,206 & 1.066 & Pc3P & 138 & 0,173 & 1.335 \\
\hline PcoP & 50 & 0,204 & 1.065 & PC4 & 697 & 0,261 & 3.023 \\
\hline PmP & 66 & 0,205 & 1.071 & Pc4P & 761 & 0,122 & 0.372 \\
\hline Total & 6184 & 0,158 & 1.196 & $\mathrm{Pn}$ & 88 & 0,176 & 0.780 \\
\hline $\begin{array}{l}\text { AN5 } \\
\text { Phases }\end{array}$ & $\begin{array}{l}\text { Number of } \\
\text { data }\end{array}$ & RMS (s) & $\mathrm{Chi}^{2}$ & PcoP & 0 & & \\
\hline Direct & 518 & 0,053 & 0.795 & PmP & 53 & 0,092 & 0.216 \\
\hline PS1 & 83 & 0,073 & 0.412 & Total & 6837 & 0,166 & \begin{tabular}{|l|l}
1.429 \\
\end{tabular} \\
\hline Ps1P & 321 & 0,083 & 0.697 & & $\begin{array}{l}\text { Pointed } \\
\text { phase } \\
\text { uncertainty } \\
\text { (s) }\end{array}$ & \multicolumn{2}{|c|}{ Glossary of seismic phases } \\
\hline PS2 & 213 & 0,119 & 1.424 & \multirow[t]{2}{*}{ Direct } & \multirow[t]{2}{*}{0.06} & \multirow{2}{*}{\multicolumn{2}{|c|}{ Direct wave through the water }} \\
\hline Ps2P & 230 & 0,073 & 0.536 & & & & \\
\hline PS3 & 92 & 0,170 & 2.934 & \multirow[t]{2}{*}{ PSn } & \multirow[t]{2}{*}{0.1} & \multirow{2}{*}{\multicolumn{2}{|c|}{$\begin{array}{l}\text { P-wave refracted phase through } \\
\text { nth sedimentary layer }\end{array}$}} \\
\hline Ps3P & 25 & 0,078 & 0.630 & & & & \\
\hline PS4 & 0 & 0 & 0 & \multirow[t]{2}{*}{ PsnP } & \multirow[t]{2}{*}{0.1} & \multirow{2}{*}{\multicolumn{2}{|c|}{$\begin{array}{l}\text { P-wave reflected phase from the } \\
\text { bottom of the nth sedimentary } \\
\text { layer }\end{array}$}} \\
\hline Ps4P & 199 & 0,105 & 1.108 & & & & \\
\hline PC1 & 2021 & 0,110 & 0.536 & \multirow[t]{2}{*}{ Pcn } & \multirow[t]{2}{*}{0.15} & \multirow{2}{*}{\multicolumn{2}{|c|}{$\begin{array}{l}\text { P-wave refracted phase through } \\
\text { the crust layer }\end{array}$}} \\
\hline Pc1P & 779 & 0,105 & 0.493 & & & & \\
\hline PC2 & 2961 & 0,138 & 0.845 & \multirow[t]{2}{*}{ PcnP } & \multirow[t]{2}{*}{0.15} & \multirow{2}{*}{\multicolumn{2}{|c|}{$\begin{array}{l}\text { P-wave reflected phase from the } \\
\text { bottom of the nth crust layer }\end{array}$}} \\
\hline Pc2P & 1807 & 0,158 & 1.109 & & & & \\
\hline PC3 & 114 & 0,143 & 0.920 & \multirow[t]{2}{*}{$\mathrm{Pn}$} & \multirow[t]{2}{*}{0.2} & \multirow{2}{*}{\multicolumn{2}{|c|}{$\begin{array}{l}\text { P-wave Moho refracted phase } \\
\text { for the upper plate }\end{array}$}} \\
\hline Pc3P & 1492 & 0,225 & 1.262 & & & & \\
\hline Pn & 289 & 0,261 & 1.703 & PcoP & 0.2 & \multicolumn{2}{|c|}{$\begin{array}{l}\text { P-wave reflected phase on the } \\
\text { top of the subducting plate } \\
\text { under the moho of the upper } \\
\text { plate }\end{array}$} \\
\hline PcoP & 54 & 0,163 & 0.677 & PmP & 0.2 & \multicolumn{2}{|c|}{$\begin{array}{l}\text { P-wave Moho reflection on the } \\
\text { bottom of the subduction plate }\end{array}$} \\
\hline PmP & 227 & 0,163 & 1.358 & & & & \\
\hline Total & 11425 & 0,150 & 0.909 & & & & \\
\hline
\end{tabular}


670 Table 2: Residual travel times for all reflected and refracted phases for AN1-AN3 and AN5 transect, 671 using forward modeling (Zelt and Smith 1992)

672

\section{OBS sections}

674 The following figures show, for each panel, (A) Ray coverage every fifth ray plotted. (B) 675 Observed travel times (colored bars) according to phases picks and calculated travel time (solid 676 lines). (C) OBS seismic section with picked phases (D) Uninterpreted OBS seismic section.

677

678 

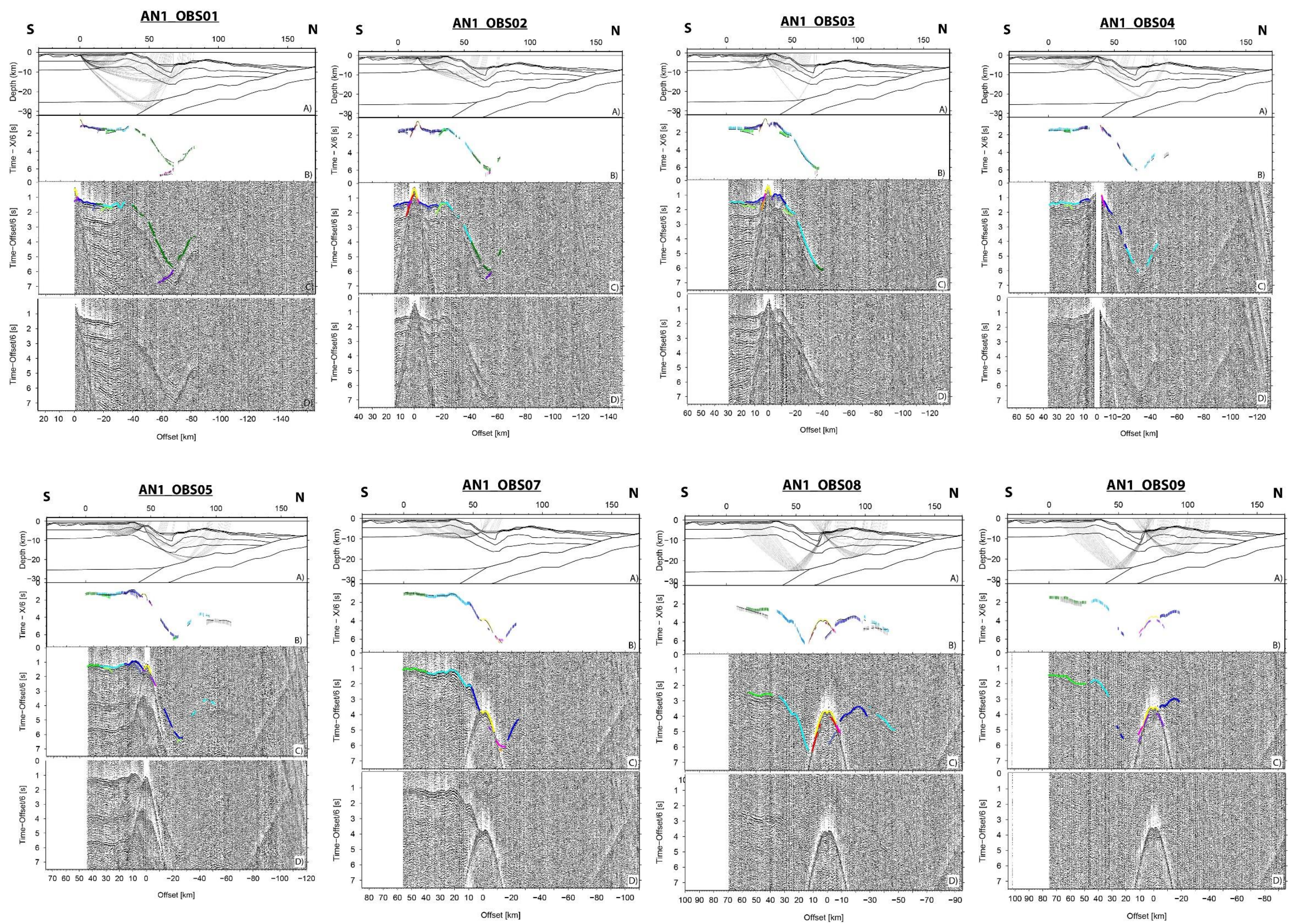

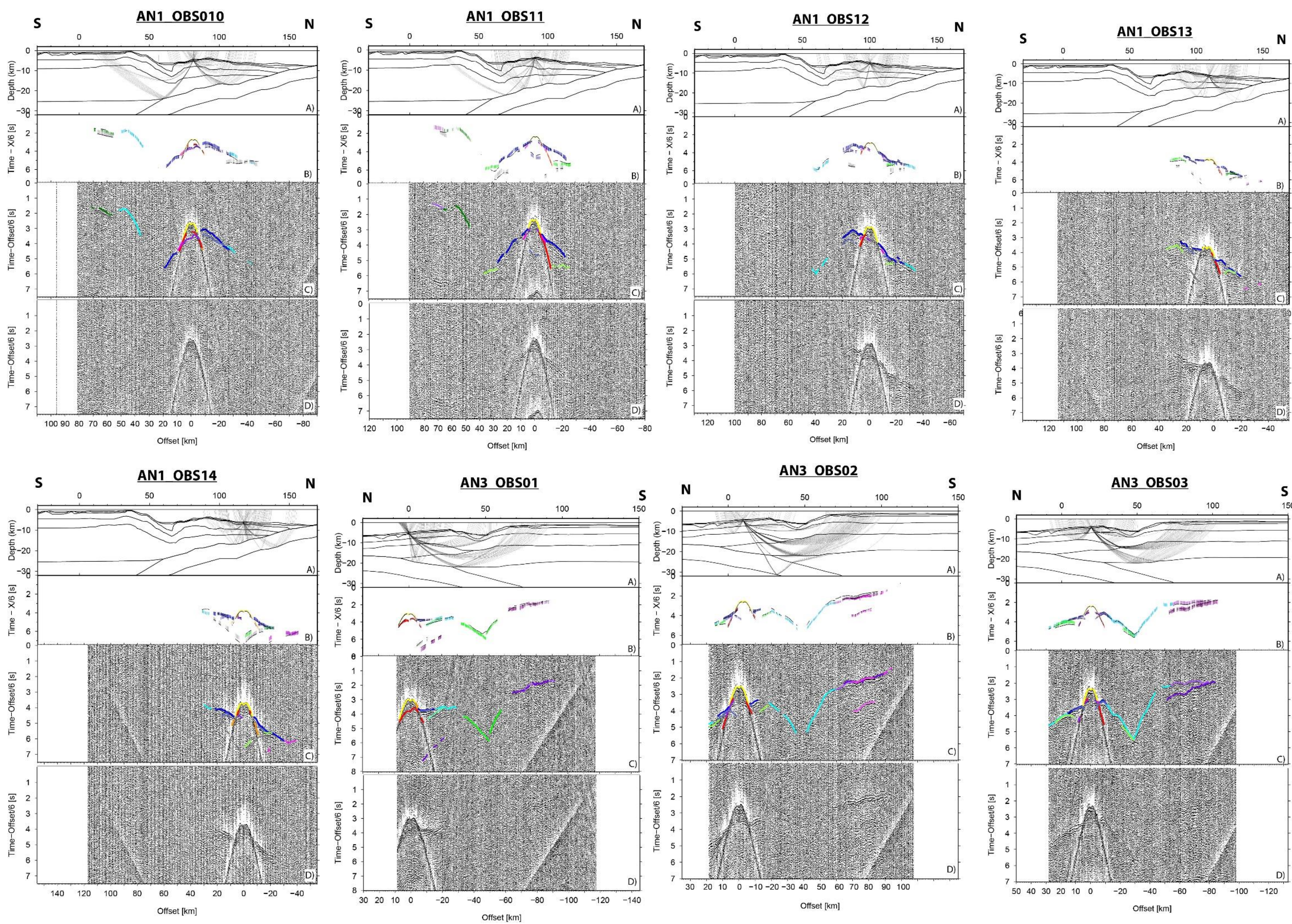

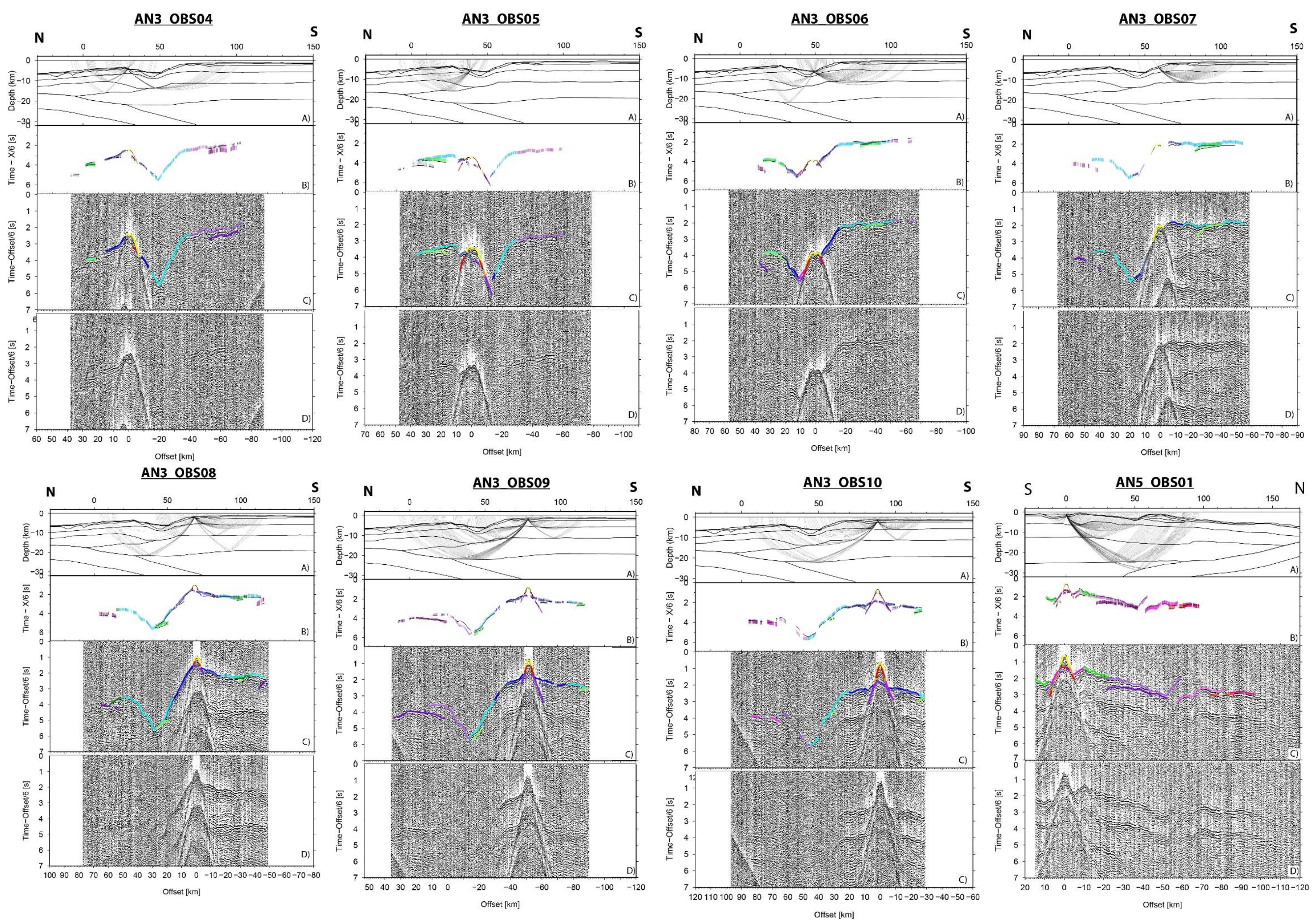

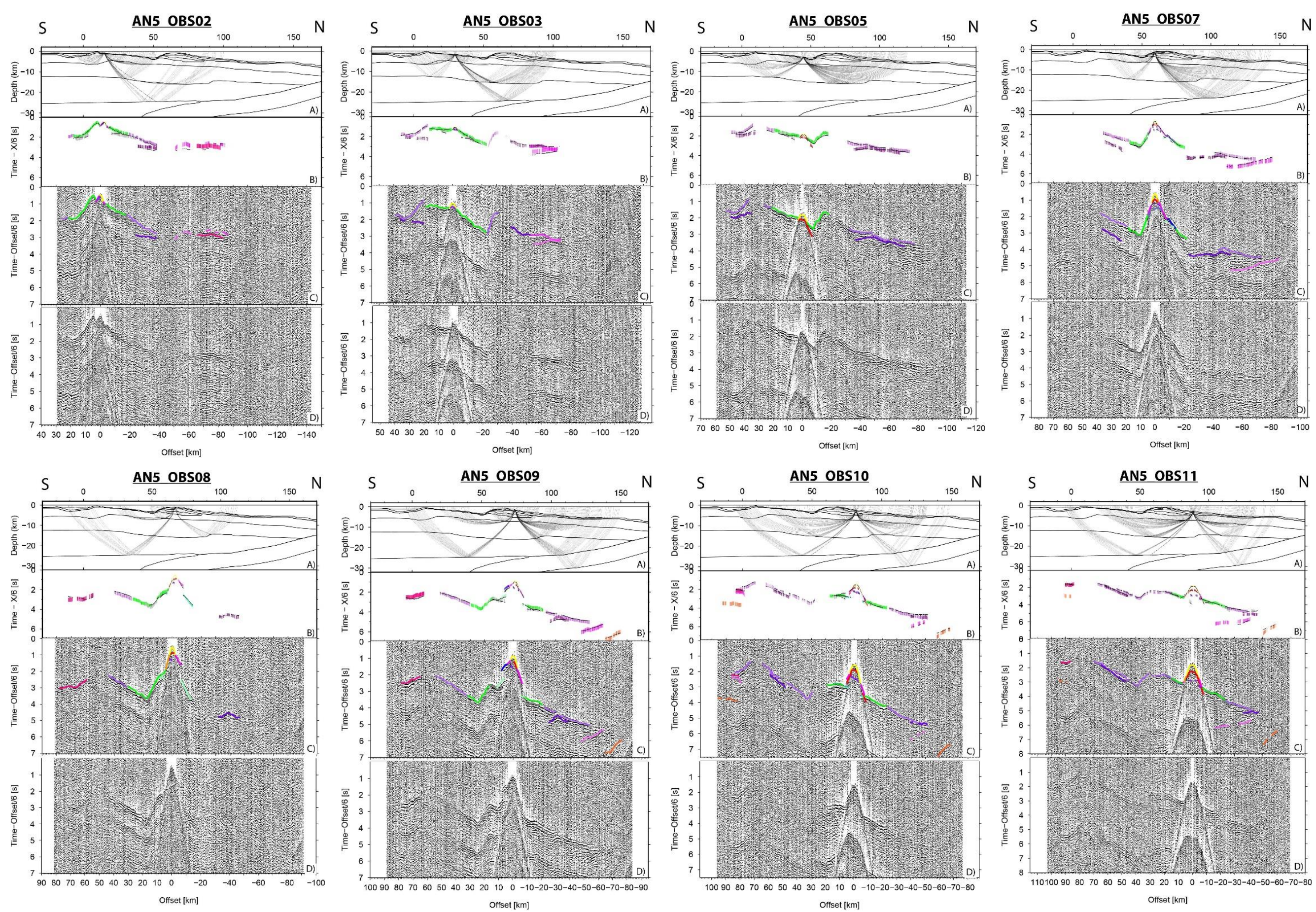


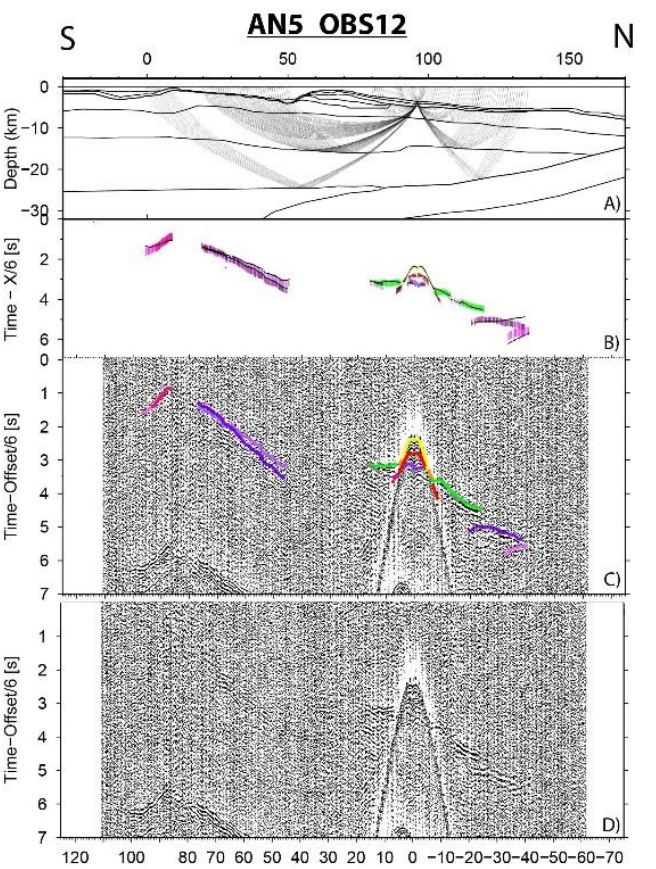

Offset [km]

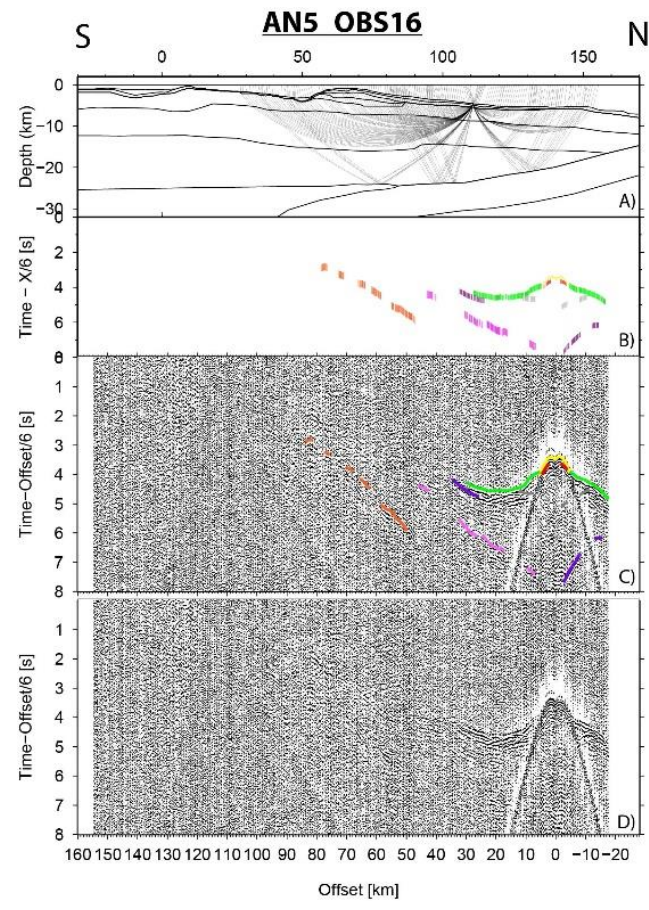
.

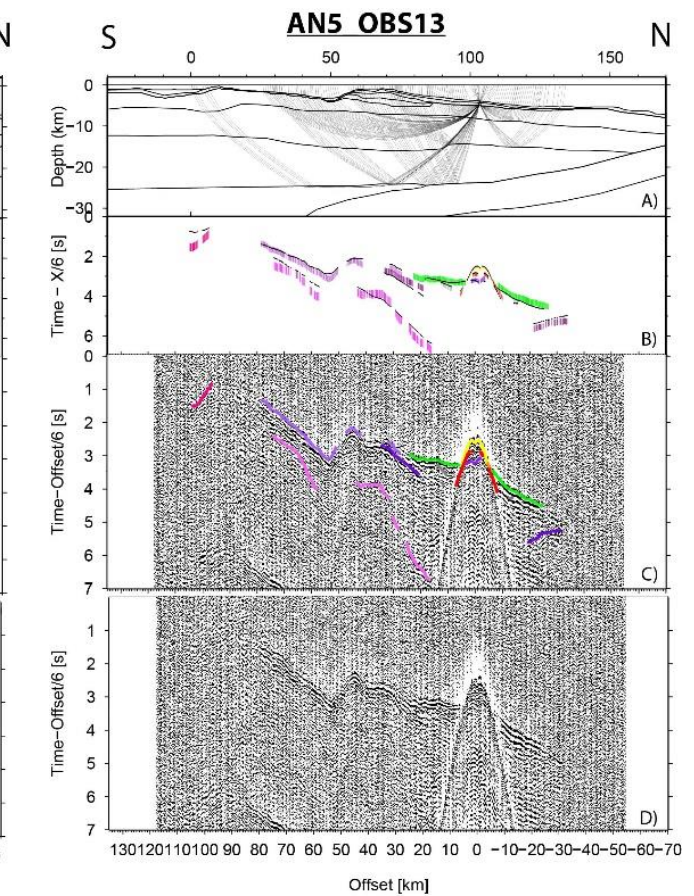

Offset [km]
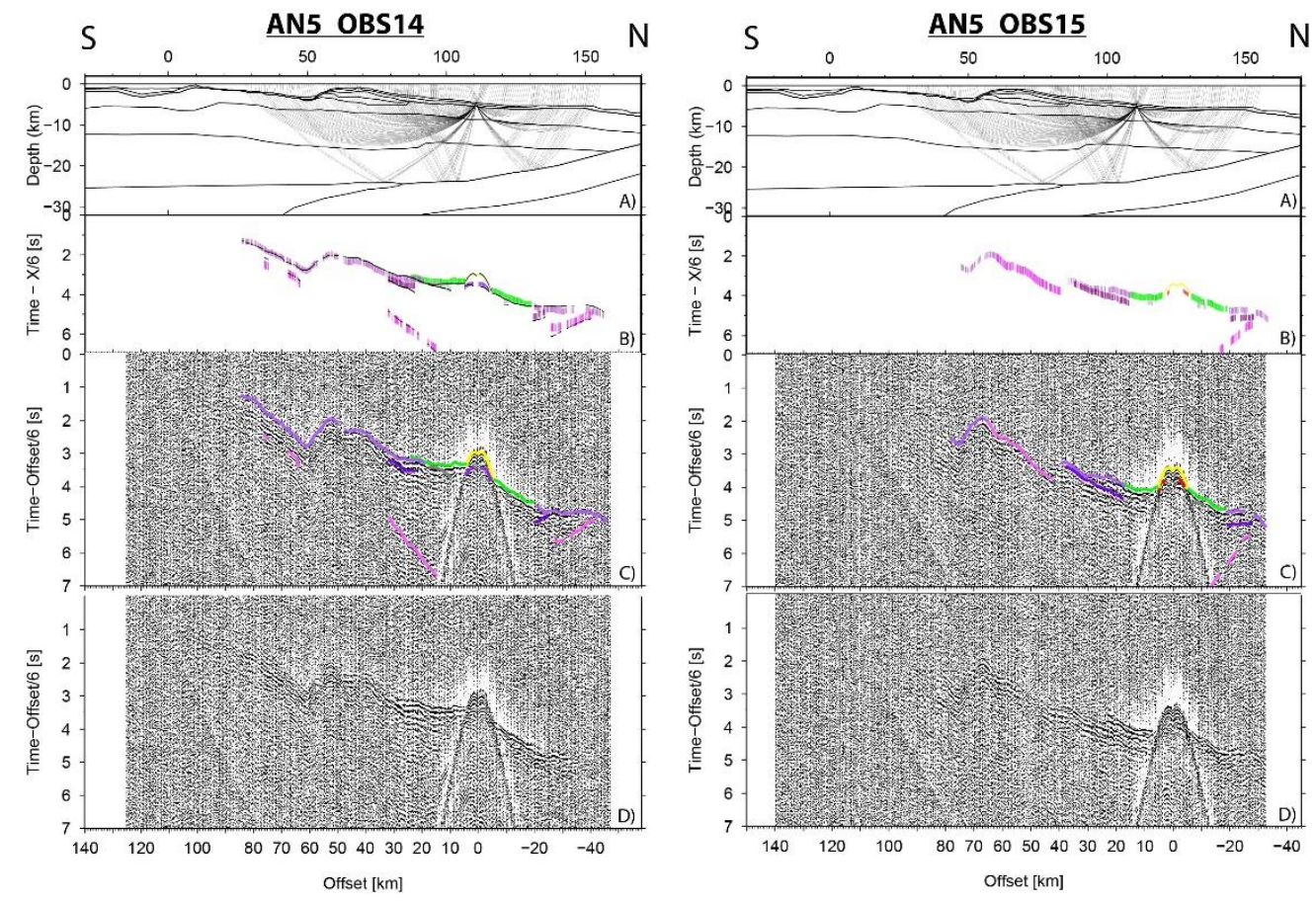